Article

\title{
Lepidoptera are Relevant Bioindicators of Passive Regeneration in Tropical Dry Forests
}

\author{
Luc Legal $1, * \mathbb{D}$, Marine Valet ${ }^{1}$, Oscar Dorado ${ }^{2}$, Jose Maria de Jesus-Almonte ${ }^{2}$, Karime López ${ }^{2}$ \\ and Régis Céréghino ${ }^{1} \mathbb{D}$ \\ 1 Laboratoire écologie fonctionnelle et environnement, Université Paul Sabatier, CNRS, \\ 31062 Toulouse, France; marine.valet.9@gmail.com (M.V.); regis.cereghino@univ-tlse3.fr (R.C.) \\ 2 Centro de Educación Ambiental e Investigación Sierra de Huautla, \\ Universidad Autónoma del Estado de Morelos, Cuernavaca 62209, Mexico; odorado@uaem.mx (O.D.); \\ almont13_fenix@hotmail.com (J.M.d.J.-A.); karimelodi@gmail.com (K.L.) \\ * Correspondence: luc.legal@univ-tlse3.fr
}

Received: 12 April 2020; Accepted: 4 June 2020; Published: 9 June 2020

\begin{abstract}
Most evaluations of passive regeneration/natural succession or restoration have dealt with tropical rain forest or temperate ecosystems. Very few studies have examined the regeneration of tropical dry forests (TDF), one of the most damaged ecosystem types in the world. Owing to their species diversity and abundance, insects have been widely used as bioindicators of restoration. Butterflies were among the most abundant and useful groups. We sampled four sites with different levels of anthropogenic disturbance in a Mexican TDF (Morelos State) and compared butterfly communities. A first goal was to examine whether adult butterflies were significant bioindicators owing to their specificity to restricted habitats. A second aim was to determine if differences exist in butterfly communities between some fields abandoned from 4-8, 8-15 and 15-30 years and a reference zone considered as primary forest. We found $40 \%$ to $50 \%$ of the species of butterflies were specifically related to a habitat and/or a level of anthropogenic disturbance. The time it takes for passive regeneration and recovery of the Mexican tropical dry forest is much higher than 25 years (our older zone), considering that almost none of the butterflies found in our conserved reference zone were present in our 25 year aged study zone.
\end{abstract}

Keywords: dry broadleaf forest; Mexico; butterflies; bioindicators; abandoned fields; Sierra de Huautla UNESCO Biosphere Reserve

\section{Introduction}

While they only represent $7.7 \%$ of the earth's land surface [1], tropical dry forests (TDFs) are home to exceptional biological diversity [2-5]. About $54 \%$ of all TDFs are located in the Americas. In Mexico, for example, TDFs (also called tropophilous forest [6], Figure A1) contain a wealth of unique biodiversity $[7,8]$ and one of the greatest levels of endemism for plants $(40 \%)$ when compared to the rainforest (5\%) [9-11]. Yet conservation efforts remain directed toward rainforests $[10,12]$. The mean annual temperature of TDFs is higher than $17^{\circ} \mathrm{C}$, and the rainfall usually ranges from 250 to $2000 \mathrm{~mm}$ [13]. The main particularity of the TDF is the contrast between rainy season (May to November) which allow the development of luxurious vegetation, and dry season (November to May) when the vegetation becomes dry and less attractive [14]. This characteristic certainly leads to the lack of interest from conservationists to create reserves. Hence, only a small fraction (9\%) of all TDFs remains intact $[1,7,15-18]$ and few conservation efforts are made with the exception of Costa Rica (Guanacaste) and three main spots in Mexico (Chamela, Sierra Gorda and The Sierra de Huautla). As a result, TDFs are among the most threatened types of tropical forests $[8,19]$. 
The main cause of the decline of TDF cover is the conversion to agriculture or extensive cattle ranching $[7,8,20,21]$ which generate degraded patches [7]. The resulting deforestation diminishes the ecological functions of the forests and adversely affects the associated biodiversity $[19,22]$. As a result of these risks and the negative perceptions of dry forests which made them unattractive $[8,16]$, there is an urgent need to support conservation efforts [23-25]. There is, however, a lack of detailed quantitative studies and much of the data required for conservation planning are incomplete or absent $[10,26,27]$.

Considering the loss of primary forest, some restoration programs have been set up to rehabilitate degraded areas by natural regeneration not directed by humans $[28,29]$. This method of passive conservation has proven to be successful with limited costs [30]. According to one study, the natural regeneration of a rainforest in Puerto Rico after pastures and coffee plantations were been abandoned, produced a secondary forest after 30 to 40 years [31]. This resulted in biodiversity similar to that of the island's mature undisturbed forest. However, it was not possible to accurately match the species composition with that of the primary forest, which means some ecosystem functions might not have been restored. Studies of passive regeneration of TDFs are comparatively scarce [32-34]. In particular, there is a lack of reliable indicators of the successional stages and ecological health of the systems during regeneration.

The dynamics of plant communities when they are subjected to environmental changes is slower than the response of their pollinators [35]. Many insects have already been used as bioindicators, including beetles, ants, grasshoppers, flies, hoverflies and butterflies [36-41]. Studying the changes in species richness of well-studied groups such as butterflies allows for characterization of the dynamics and disturbance levels of biodiversity in temperate and tropical areas [14,42-46]. Lepidoptera species are highly sensitive to climate change and environmental factors such as temperature or precipitation range [47]. They also have the advantage of being considered "flagship taxa" that capture the attention of environmental managers [48,49]. In tropical forests, species richness decreases with increasing habitat degradation [50]. Within a given genus, some species have a high mutual exclusion rate and are reduced to very specific ecological niches [41]. Around 1825 species of butterflies exist in Mexico, and approximately 500 of them have been recorded in Sierra de Huautla Biosphere Reserve (REBIOSH), a TDF protected area in Morelos, Mexico [43]. In March 1993, the Morelos State declared that most of the southern part of the state was subject to an ecological conservation plan (first as a state reserve then in 1999 with the Mexican biosphere status), mainly focused on intact or near-intact TDFs. Since 2006, this protected area is a UNESCO Biosphere Reserve (Figure A2). The history of soil management around the villages of the REBIOSH is well known. After the disappearance of extensive farms (fincas) following the Mexican revolution led by Emiliano Zapata (1910), former farm workers slowly restarted subsistence farming. The population gradually declined since the 1970 's due to emigration, mainly to the USA [51]. One of the consequences was that many agricultural fields were abandoned, resulting in a spontaneous succession of plants and animals.

The aim of this work was to evaluate whether butterfly communities could be used as ecological markers of a dry tropical forest regeneration following abandonment of cultivation.

In order to answer our question, we sampled butterfly species in four different sites representing four different successional stages (i.e., sites differing in the number of years since cultivation was abandoned). We examined whether the dynamics of the butterfly community across successional stages denoted a return to the reference composition represented by the most preserved zone. The species richness and the species composition during the rainy and dry seasons were evaluated. The use and the limits of adult Lepidoptera as bioindicators for studying dry tropical forest dynamics was further discussed. 


\section{Materials and Methods}

\subsection{Study Sites}

The four study sites were located in the REBIOSH, close to the village and the biological station of El Limon (Figure 1). All four sites were selected on the basis that they shared similar environmental characteristics: elevation, slope orientation and gradient, geology and pedology. Moreover, their proximity ensured that they were subject to the same precipitation patterns. Each site was characterized by a specific time period of non-exploitation for agriculture. Zone A has not been exploited for 5-6 years (knowing that our sampling was done in two consecutive years), Zone B for 11-14 years (with a small range of uncertainty) and Zone C for 25-26 years. The history of human exploitation of fields in this region is difficult to trace. This is why, in addition to the practical difficulty of collecting insects, it was not possible to perform replications on plots with equivalent orientation, altitude and humidity conditions between them.

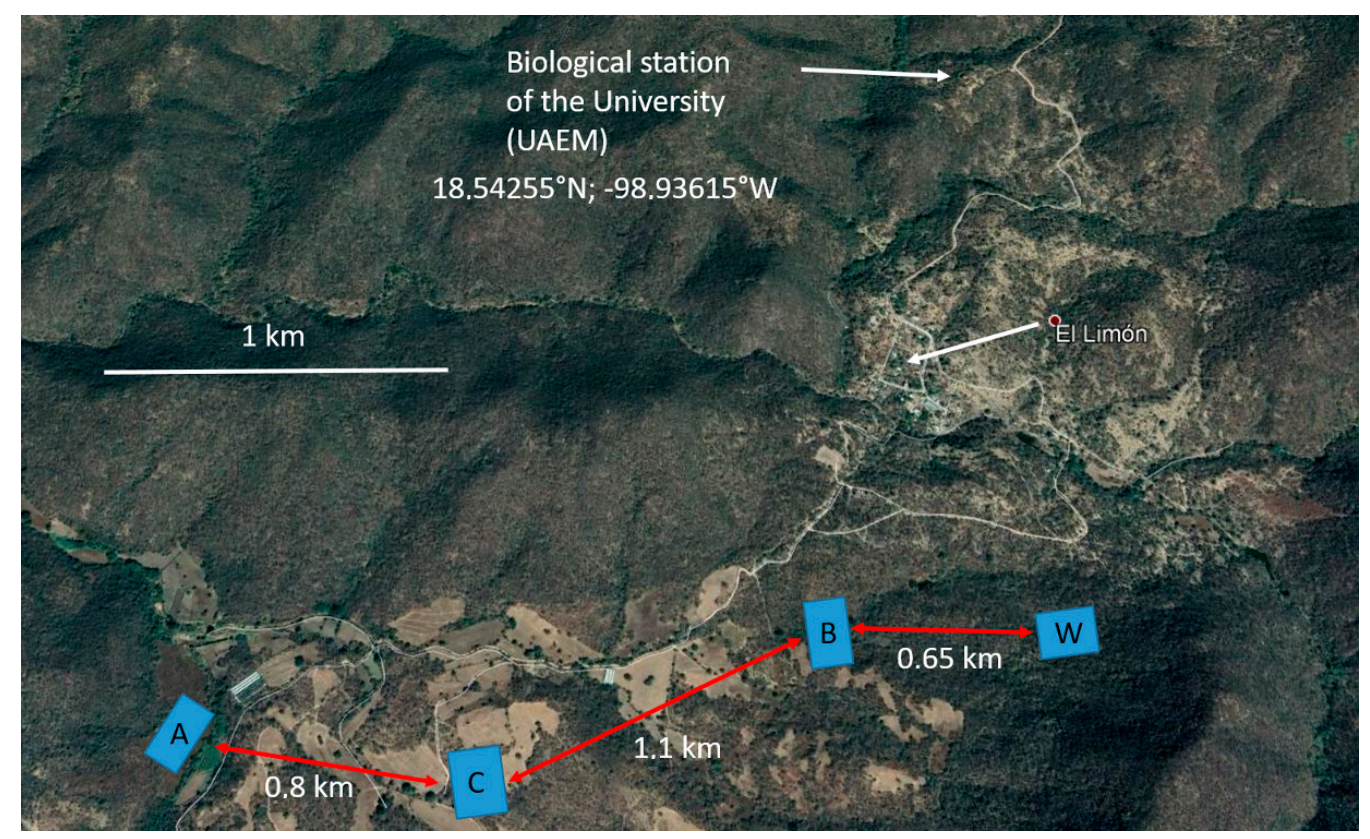

Figure 1. Localities of sampling (northeast of the Biosphere reserve of the Sierra de Huautla, Morelos State, Mexico (see Figure A2)). Reference: biological station of “El Limon" 18³2'33.12" N; 98 56'10.22" W (Source: INEGI/CNES 2020). Zone A has not been exploited for 5-6 years; Zone B for 11-15 years; Zone C for 25-26 years; and Zone Wild (W) the reference, representing primary dry tropical forest. Each sampling zone (in blue) is a 2 ha plot, approximately $180 \times 110 \mathrm{~m}$.

The Wild Zone (W) was our reference of primary (undisturbed) TDF (Figure 1). Zone A is an open field with only herbaceous vegetation; Zone B is characterized by small shrubs; Zone C is similar to Zone B, but the percentage of tree cover is higher. The size of each sample plot (forest patch) is 2 ha. We did not sample close to the edges to avoid possible biases due to ecotone vegetation.

From early January until the end of May, the trees are leafless, and the herbaceous vegetation cover is low. From June to the end of December, the vegetation is luxurious (see [52] for pictures). Therefore, we separated our sampling into two sets, namely dry season and rainy season, based on the vegetation cover.

\subsection{Butterfly Sampling}

Our sampling covered two successive years in order to have a replicate for both the rainy and dry season. The butterflies were collected with a standard Lepidoptera hand net (handle $1.5 \mathrm{~m}$ long, net diameter $40 \mathrm{~cm}$ ) for one hour, one day per month and per zone. To limit data collection bias, 
only one of us (LL) performed all the sampling. Some species were collected a single time and were excluded from analysis (of the 119 species collected, 93 were included in the analyses). The two years of sampling were compiled after performing preliminary analyses and the average values used for further analysis.

\subsection{Data Analyses}

\subsubsection{Diversity Indices}

We calculated Shannon's entropy and Simpson's evenness indices every month at each site to evaluate and compare spatial and temporal changes in diversity. The Chao1 index (calculated using EstimateS@ 8.20 software) was used to estimate the species richness [53]. The $\alpha$-diversity was recorded at each site and compared to Chao1 estimates.

We estimated overall beta diversity $(\beta c c)$ partitioned by its components, species richness differences ( $\beta$ rich) and species replacement $(\beta-3)[54,55]$. $\beta c c$ represents the proportional effective species turnover. Interestingly, these components are additive (i.e., $\beta c c=\beta$ rich $+\beta-3$ ), as previously demonstrated [55] and reflect the breakdown of the constituents of $\beta$-diversity in the loss or gain and the replacement of species between communities.

\subsubsection{Species Distribution Patterns}

Ecological data such as organism counts often vary and co-vary in a nonlinear fashion. Nonlinear modeling methods such as artificial neural networks (ANNs) were therefore deemed relevant to analyze shifts in species distributions among our study sites (A, B, C and W), in relation to humidity, drought or vegetation cover. Specifically, we used the self-organizing map algorithm (SOM; [56]), which combines ordination, clustering and gradient analysis.

The network consisted of 28 independent samples ( 4 sites $\times 7$ months) in the rainy season, 20 in the dry season ( 4 sites $\times 5$ months), characterized by 93 butterfly species (descriptors) for the rainy season and 42 species for the dry season. A vector that includes all descriptors represents each sample, and there are as many vectors as samples. The input layer is comprised of $p$ nodes, or neurons. The output layer forms a rectangular two-dimensional map with neurons laid out over a hexagonal lattice. Each neuron of the output layer is also called a "cell" (visualized as a hexagon) and is linked to the neurons of the input layer by connections that have weights associated with them, forming a vector.

These weights represent the virtual values for each descriptor in every output neuron such that every cell in the output layer stores a virtual vector of connection weight. These virtual vectors characterize the coordinates of the centers from groups of similar input vectors, where similarity is measured in terms of Euclidean distance for all neurons. The aim of the SOM is to organize the distribution of sample vectors in a two-dimensional space, using their relationship to the virtual-vector distribution. Similar input vectors are allocated to the same virtual vector and it changes with the addition of new input vectors. The virtual vectors that are neighbors on the map (neighboring neurons) are expected to represent neighboring groups of sample vectors. Consequently, sample vectors that are dissimilar are likely to be distant from each other on the map. The SOM units (hexagons) were divided into clusters according to the weight vectors of the neurons, and clusters were justified according to the lowest Davis-Bouldin index, i.e., for a solution with low variance within clusters and high variance between clusters [57].

\subsubsection{Cladistic Analysis}

A matrix was created based on presence/absence and relative abundances for every month and zone. Different patterns are visible, which allowed us to qualify the specificity of each species sampled. We coded the observed degree of openness of the living environment for each species as follows: "open," A; "shrubs," B and C; "trees," W. Humidity conditions were divided into the three following categories: xeric $(*)$, semi-xeric or moderately humid $\left(^{* *}\right)$ and humid $\left({ }^{* * *}\right)$. We noted 0 : absence; 1 : one 
isolated individual; 2: two to seven individuals; 3: 8 to 15 individuals and 4: more than 15 individuals. The data set was split in two: rain season and dry season, as mentioned above. Only the rain season is presented here (most of the dry season's butterflies are generalist species). A cladogram was generated using PAUP* $4.0 \mathrm{~b} 10$ software [58], with all characters organized (Wagner) in order to use the abundance data for each species. Starting trees were obtained by stepwise addition. All heuristic searches for optimal trees were carried out by TBR (tree bisection and reconnection) branch swapping.

We did not attempt to conduct a phylogenetic classification. Thus, we decided not to include any outgroup in our data set so that the tree was unrooted. As some multiple subequal trees were found, a majority rule $(50 \%)$ consensus tree was calculated.

Considering the presence per sites, we checked if species from the same zone were represented together. Specialized species from one zone were expected to be grouped in the same clade, contrary to the habitat and/or distribution generalists (the term generalist in this work does not include host-plant generalists, rather it refers to the specificity for a type of habitat within an ecosystem).

In order to test our hypothesis, a comparison was made between the theoretical habitat of each species and the results obtained using the SOM approach. When congruence was found between the cladistics approach and SOM analysis, we annotated Y, and when congruence was not found, we annotated $\mathrm{N}$. When a species was considered a generalist for one approach (theoretical or observed) and considered a specialist for the other, we noted 0 . When its theoretical habitat tended to be like the SOM result but there was no $100 \%$ congruence, we termed it tendency. A bioindicator in a strict sense is a species found in one type of habitat and when the congruence is " $Y$ ". The two sites (B and C) have been considered together.

\section{Results}

We found 119 species from five families (Papilionidae, Pieridae, Nymphalidae, Lycaenidae (including Riodininae) and Hesperiidae), (Table A1). A total of 5122 individuals were collected and identified. Individuals belonging to Codatractus melon and Codatractus sallye (Hesperiidae, Eudaminae) were pooled due to uncertain identification. Twenty-six rare species (less than 10 individuals in two years) were removed from the dataset prior to analysis to avoid biases due to the low number of individuals collected. We thus retained 93 species. The most common species was Eurema daira (556 individuals in total), followed by Pyrisitia proterpia and Nathalis iole (229 and 160 individuals, respectively). All three species belong to Pieridae, Coliadinae.

\subsection{Diversity Indices}

In the rainy season, Shannon's entropy almost doubled compared to the dry season (dry season: 1.51, rainy season: 2.71) (Table 1). Shannon index values did not differ significantly among sites for both seasons. However, higher diversity was always found in August in the four zones. Simpson's evenness differed between the dry and rainy season (respectively average/season 0.66 and 0.88 ) but not within seasons for the four zones. 
Table 1. Various diversity indices by months (first set is the dry season, second set is the rain season) and by sites (A, B, C and W). Highlighted in gray are the highest values per season for each site.

\begin{tabular}{|c|c|c|c|c|c|c|}
\hline & Shannon (H) & Simpson (1-D) & H Mean & (1-D) Mean & Chao1 & Div Alpha \\
\hline \multicolumn{7}{|l|}{ Dry Season } \\
\hline Zone A (open) & & & 1.44 & 0.58 & 12.27 & 11.8 \\
\hline January & 1.26 & 0.50 & & & & \\
\hline February & 0.86 & 0.35 & & & & \\
\hline March & 1.51 & 0.64 & & & & \\
\hline April & 2.17 & 0.78 & & & & \\
\hline May & 1.39 & 0.61 & & & & \\
\hline Zone B (shrubs) & & & 1.55 & 0.73 & 8 & 6.8 \\
\hline January & 1.84 & 0.79 & & & & \\
\hline February & 1.52 & 0.74 & & & & \\
\hline March & 1.43 & 0.72 & & & & \\
\hline April & 1.58 & 0.74 & & & & \\
\hline May & 1.40 & 0.68 & & & & \\
\hline Zone C (shrubs) & & & 1.55 & 0.69 & 8.17 & 7.4 \\
\hline January & 1.11 & 0.47 & & & & \\
\hline February & 1.63 & 0.75 & & & & \\
\hline March & 1.81 & 0.82 & & & & \\
\hline April & 1.70 & 0.78 & & & & \\
\hline May & 1.48 & 0.65 & & & & \\
\hline Zone W (forest) & & & 1.51 & 0.65 & 13 & 11.6 \\
\hline January & 0.88 & 0.40 & & & & \\
\hline February & 1.13 & 0.55 & & & & \\
\hline March & 1.60 & 0.72 & & & & \\
\hline April & 1.70 & 0.73 & & & & \\
\hline May & 2.24 & 0.86 & & & & \\
\hline \multicolumn{7}{|l|}{ Rainy Season } \\
\hline Zone A (open) & & & 2.88 & 0.89 & 44.53 & 34.57 \\
\hline June & 2.87 & 0.93 & & & & \\
\hline July & 3.13 & 0.91 & & & & \\
\hline August & 3.36 & 0.94 & & & & \\
\hline September & 3.03 & 0.89 & & & & \\
\hline October & 2.98 & 0.90 & & & & \\
\hline November & 2.62 & 0.85 & & & & \\
\hline December & 2.19 & 0.83 & & & & \\
\hline Zone B (shrubs) & & & 2.64 & 0.88 & 28.89 & 25.86 \\
\hline June & 2.47 & 0.87 & & & & \\
\hline July & 3.08 & 0.94 & & & & \\
\hline August & 3.19 & 0.94 & & & & \\
\hline September & 2.78 & 0.92 & & & & \\
\hline October & 2.78 & 0.89 & & & & \\
\hline November & 2.27 & 0.84 & & & & \\
\hline December & 1.70 & 0.74 & & & & \\
\hline Zone C (shrubs) & & & 2.49 & 0.83 & 30.20 & 25.43 \\
\hline June & 1.70 & 0.70 & & & & \\
\hline July & 2.85 & 0.91 & & & & \\
\hline August & 3.13 & 0.93 & & & & \\
\hline September & 2.99 & 0.93 & & & & \\
\hline October & 2.80 & 0.91 & & & & \\
\hline November & 2.82 & 0.90 & & & & \\
\hline December & 1.15 & 0.52 & & & & \\
\hline Zone W (forest) & & & 2.83 & 0.91 & 31.90 & 28.14 \\
\hline June & 2.52 & 0.90 & & & & \\
\hline July & 2.90 & 0.91 & & & & \\
\hline August & 3.21 & 0.94 & & & & \\
\hline September & 3.16 & 0.95 & & & & \\
\hline October & 3.04 & 0.92 & & & & \\
\hline November & 2.96 & 0.93 & & & & \\
\hline December & 2.01 & 0.80 & & & & \\
\hline
\end{tabular}


On average, the $\alpha$-diversity (28.5 versus 9.4) and Chao values (33.9 versus 10.4) were about three times higher during the rainy season than the dry season (Table 2). Zone A during the rainy season showed greater values for overall diversity. For both seasons, the shrubby zones (B and C) were the least diverse.

Table 2. $\beta$-diversity values between sites (ZA to $\mathrm{ZW}$ : Zone $\mathrm{A}, \mathrm{B}, \mathrm{C}$ and $\mathrm{W}$; see Material and Methods/Study sites for more details) and between seasons (see Material and Methods for calculations). Above diagonal calculated values [ $\beta \mathrm{cc}(\beta$ rich $+\beta-3)$ ], below diagonal, “a,b,c " values (see Material and Methods); $a$ is the number of species common to both sites, $b$ is the number of species exclusive to the first site, and $c$ is the number of species exclusive to the second site.

\begin{tabular}{|c|c|c|c|c|c|c|c|c|}
\hline & ZAsec & ZArain & ZBdry & ZBrain & ZCdry & ZCrain & ZWdry & ZWrain \\
\hline ZAdry & & $\begin{array}{l}0.59(0.56 \\
+0.03)\end{array}$ & $\begin{array}{l}0.67(0.24 \\
+0.43)\end{array}$ & & $\begin{array}{l}0.66(0.41 \\
+0.25)\end{array}$ & & $\begin{array}{l}0.64(0.13 \\
+0.51)\end{array}$ & \\
\hline ZArain & $28 ; 1 ; 40$ & & & $\begin{array}{l}0.43(0.05 \\
+0.38)\end{array}$ & & $\begin{array}{l}0.43(0.14 \\
+0.29)\end{array}$ & & $\begin{array}{l}0.59(0.10 \\
+0.49)\end{array}$ \\
\hline ZBdry & $11 ; 15 ; 7$ & & & $\begin{array}{l}0.79(0.67 \\
+0.12)\end{array}$ & $\begin{array}{c}0.5(0.14 \\
+0.36)\end{array}$ & & $\begin{array}{l}0.59(0.17 \\
+0.42)\end{array}$ & \\
\hline ZBrain & & $47 ; 20 ; 16$ & $14 ; 4 ; 49$ & & & $\begin{array}{l}0.36(0.09 \\
+0.27)\end{array}$ & & $\begin{array}{c}0.43(0.08 \\
+0.35)\end{array}$ \\
\hline ZCdry & $11 ; 17 ; 4$ & & $11 ; 7 ; 4$ & & & $\begin{array}{c}0.78(0.72 \\
+0.06)\end{array}$ & $\begin{array}{l}0.69(0.29 \\
+0.40)\end{array}$ & \\
\hline ZCrain & & $44 ; 22 ; 11$ & & $47 ; 17 ; 10$ & $13 ; 2 ; 45$ & & & $\begin{array}{c}0.48(0.03 \\
+0.45)\end{array}$ \\
\hline ZWdry & $14 ; 15 ; 10$ & & $12 ; 6 ; 11$ & & $10 ; 5 ; 13$ & & & $\begin{array}{c}0.67(0.57 \\
+0.10)\end{array}$ \\
\hline ZWrain & & $36 ; 30 ; 21$ & & $43 ; 19 ; 13$ & & $39 ; 19 ; 17$ & $20 ; 3 ; 37$ & \\
\hline
\end{tabular}

When comparing $\beta$-diversity values (overall $\beta$-diversity: $\beta c c=\beta$ rich $+\beta-3$, average values from Table 2, see also Material and Methods section), we observed that between seasons, the greater component (in bold) was the species richness differences $(0.71=\mathbf{0 . 6 3}+0.08)$ while between sites (for dry $0.62=0.23+\mathbf{0 . 3 9}$ and rainy season $0.45=0.08+\mathbf{0 . 3 7}$ ) the greater component (in bold) was the species replacement.

\subsection{Species Distribution Patterns}

\subsubsection{Rainy Season}

The sites/dates were classified into four subsets, forming distinct clusters (Figure 2. Cluster 1 corresponded to Zone A from July to October (humid and the most open locations), Cluster 4 represented Zone $W$ from June to November (humid and closed areas), Cluster 2 was composed of Zone $W$ in December, Zones A,B and C in June, November, and December and Zone B in October, illustrating rather dry periods in shrubby areas. Cluster 3 showed a mixture of Zone B from July to September and Zone C from July to October (that is, the peak of rainy season in shrubby areas).

The SOM map showed the strength of the association of each species with a type of habitat/date along two gradients. The vertical gradient on the SOM was related to openness (lack of cover) of the location and the horizontal gradient portrayed the humidity level of the location (Figure 2). 


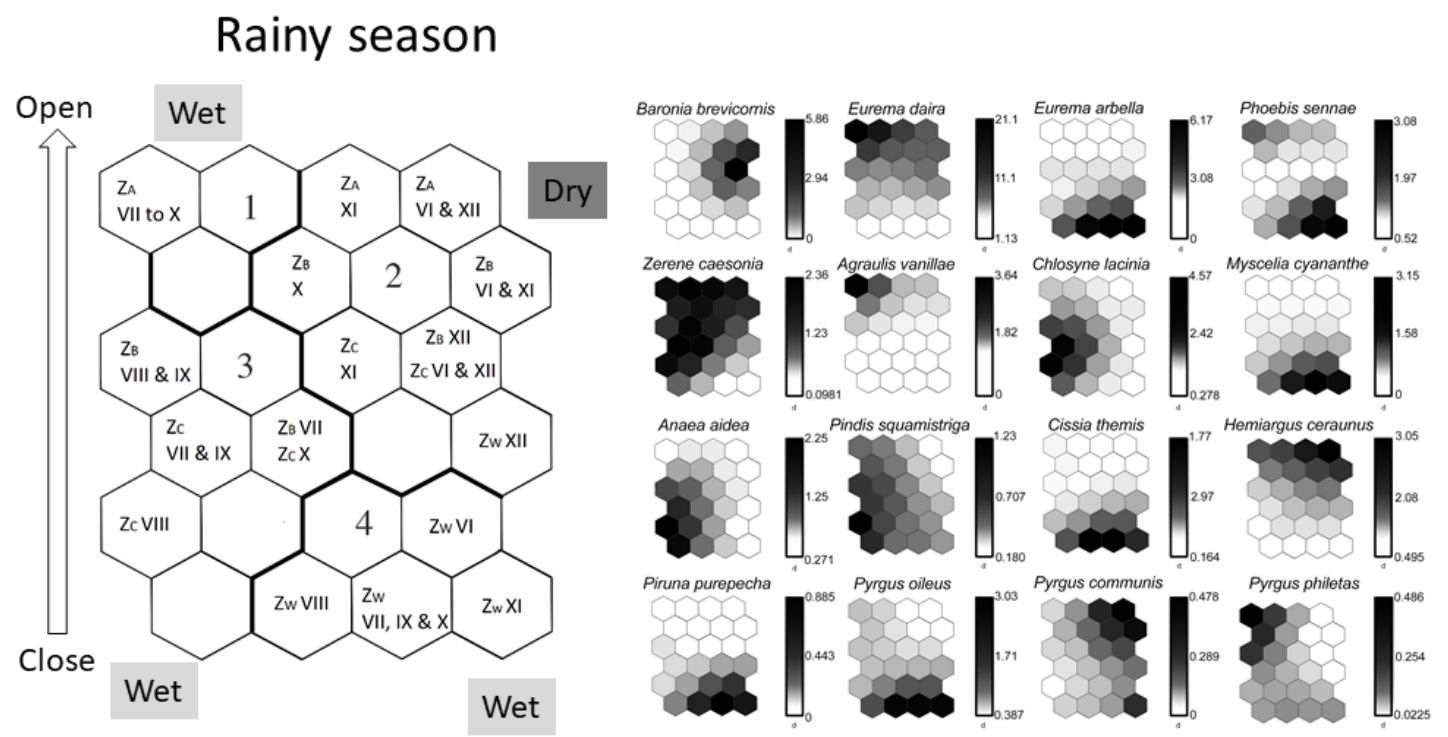

Figure 2. Probabilities of occurrence and distribution (SOM) of sampled Lepidoptera for rainy season. Left side: Kohonen (SOM) map for the four studied sites (2 years of sampling). Four clusters can be distinguished. Cluster 1: humid + open field; Cluster 3: humid + shrubs; Cluster 4: humid + conserved forest; Cluster 2: driest months of the rain season independent of type of habitat. Roman numerals are months, from I = January to XII = December). Zones A to W are noted Za to Zw. Right side: Gradient analysis of the abundance of Lepidoptera on the trained SOM represented by a shaded scale (dark = high abundance, light $=$ low abundance). Each small map representing species can be compared to (or superimposed on) the map of Kohonen, thus showing the distribution patterns of the various taxa (in shades of gray) within each subarea of the SOM. Generalist species are indicated when SOM patterns are almost black. On the right of each map, the relative scale of occurrence probabilities is shown.

Figure 2 showed a selection of species representing most distribution patterns encountered in our sampling, including very common generalist species such as Zerene cesonia (Coliadinae) but rare in preserved areas, regular generalist species with a preference for closed but humid locations such as Pindis squamistriga (Satyrinae), species specialized in one type of habitat (humid closed forests) such as Eurema arbella (Coliadinae), or in contrast, Agraulis vanillae (Heliconiinae) for open habitat. A single species (among all collected during this study) was specialized on dry shrub areas (Baronia brevicornis, Baroniinae). We noted that the three species of the genus Pyrgus (Pyrginae), all generalists, each show a clear tendency for having their own specific habitat.

The highest probability of occurrence for a species during the rainy season (21.1; Figure 2) was for Eurema daira (Coliadinae), which showed a clear preference for open/dry locations during the rainy season. Note that among the genus Pyrgus, the rate of occurrence of the two species Pyrgus communis (0.478) and Pyrgus philetas (0.486) was much lower than for the third species, Pyrgus oileus (3.03).

\subsubsection{Dry Season}

The sites/dates were classified into three clusters (Figure 3). These clusters were less defined than those of the rainy season. Cluster 2 was composed of the driest and open locations, mainly corresponding to Zone A. Clusters 1 and 3 were linked. Cluster 1 was composed of the most humid and closed locations of the zone $\mathrm{W}$, while Cluster 3 consisted of the two driest/hottest locations/dates (Zone A, March and April, often above $40^{\circ} \mathrm{C}$ ). 


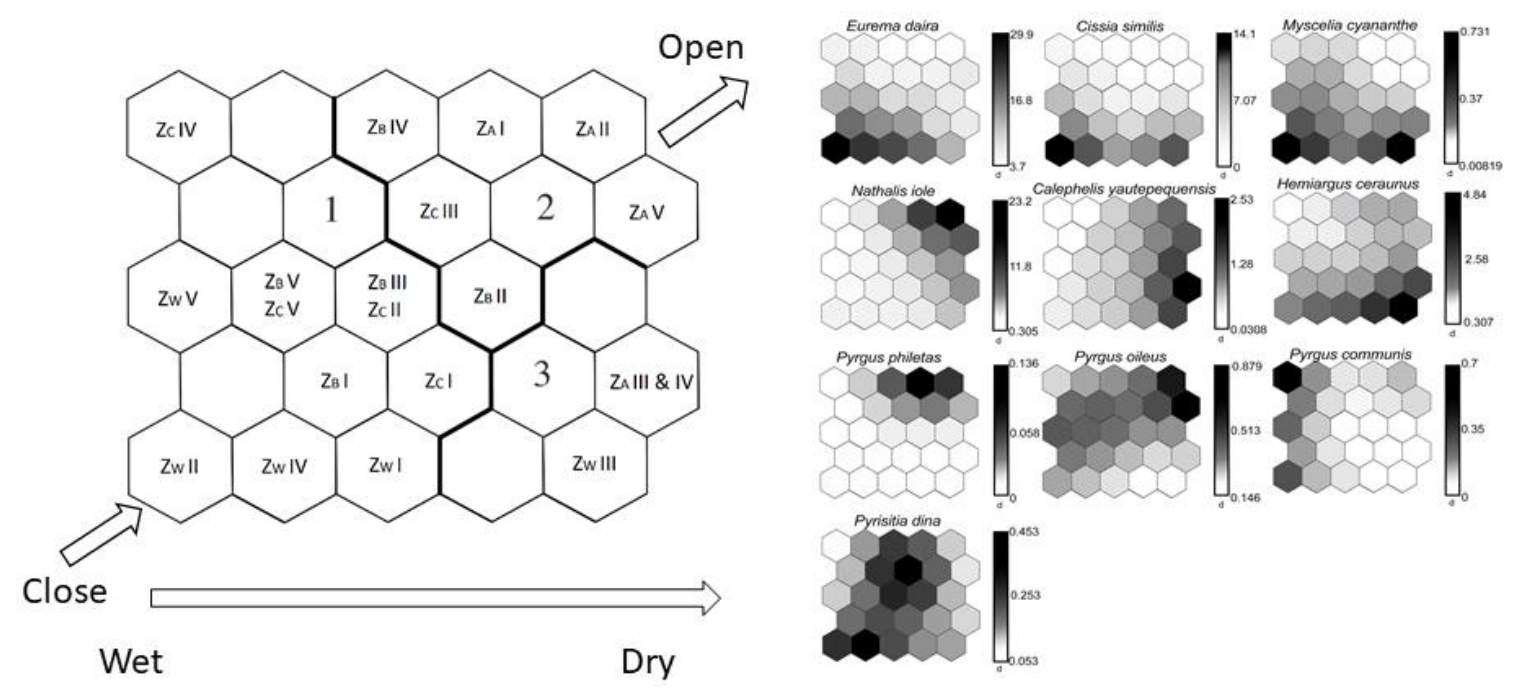

Figure 3. Probabilities of occurrence and distribution (SOM) of sampled Lepidoptera for dry season. Left side: Kohonen (SOM) map for the four studied sites (2 years of sampling; roman numerals are months, Zones A to $\mathrm{W}$ are noted $\mathrm{Za}$ to $\mathrm{Zw}$ ). Horizontal gradient from left to right side denotes from humid to dry. Diagonal from left bottom corner to up right is from closed to open habitat. See Figure 2 for more information.

A horizontal gradient of humidity was rather clear on the SOM. There was also a gradient of openness (from close to open areas) from lower-left to upper-right in the Kohonen map. The two Coliadinae, Eurema daira and Nathalis iole, dominated the selection of species presented here. Interestingly, the first species was, for the dry season, specialized in closed humid areas while it occurred in open field during the rainy season. The second species, N. iole, was more frequent in open areas during the dry season, as were some species such as Calephelis yautepequensis.

Considering the Pyrgus genus, Pyrgus oileus was shown to be a rather generalist species but the two other Pyrgus species were more specialized, especially Pyrgus communis which had a higher probability of occurrence during the dry season (dry: 0.7 ; rainy: 0.48 ). Some species showed a similar probability of occurrence independent of the season, e.g., E. daira (dry: 29.9; rainy: 21.1) and Hemiargus ceraunus (dry: 4.84; rainy: 3.66), while most species, such as Myscelia cyananthe (dry: 0.73; rain: 3.15), were more scarce during dry the season.

\subsection{Cladistic Analysis}

Generalist species (black lines, Figure 4) were all at the end of the spiral tree, leading us to assume that the most specialized species were placed in the center of the spiral. Baronia brevicornis, taking into account both flight periods and locations, was found to be the most specialized species of our sampling, while Eurema daira, a common species from USA to Argentina flying all year round, was our most generalist species. A first group of species corresponding to shrub specialists was at the center of the spiral (blue lines), followed by species specialized in primary forest (green lines). Open field specialist species were grouped (orange lines), followed by some less specialized shrub species and then by the generalist species (black lines). As mentioned above, most of these generalist species were also those with wider overall distribution in the Americas. 


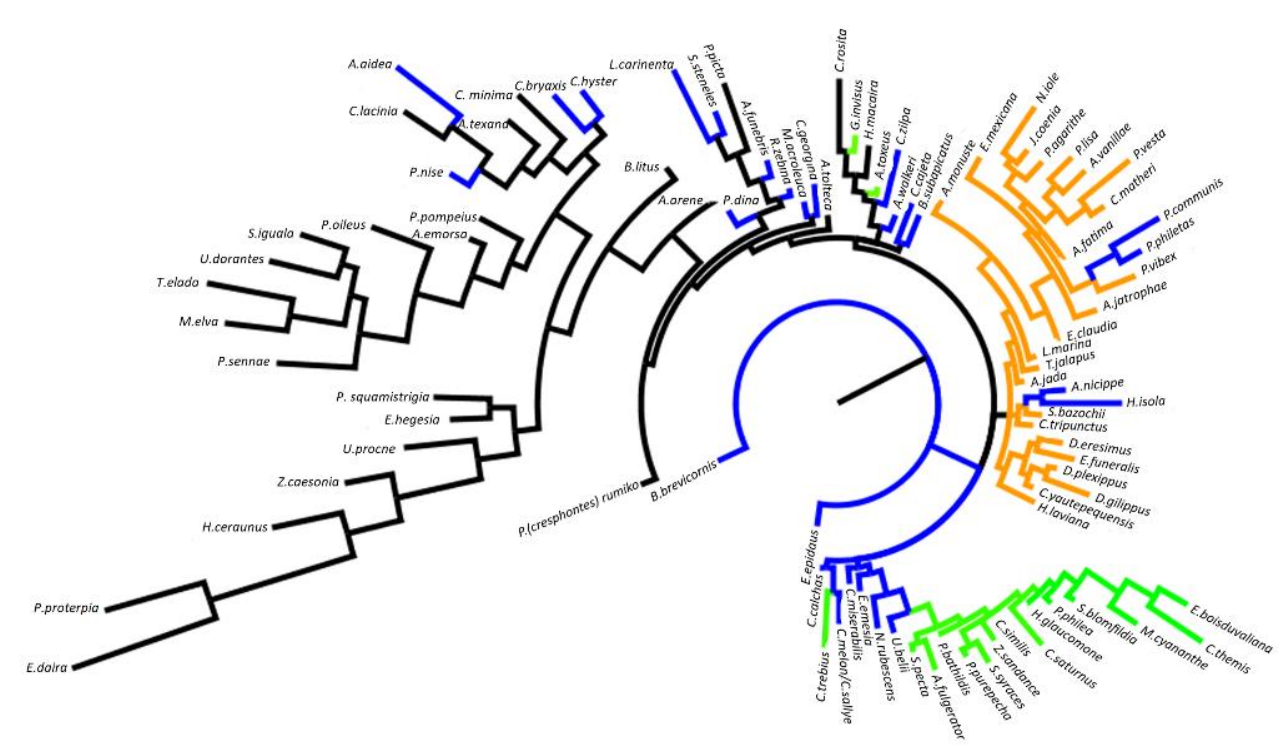

Figure 4. Cladistic tree based on presence/absence and relative abundances for every month and zone, and the degree of openness of the living environment for each species and humidity conditions. A pattern code was attributed to each species depending on the type of vegetation. Green is for species found only or preferably (more than 60\%) in the forest (Zone W); blue is for species found only or preferably in zones covered by shrubs (Zones B and C); orange is for species found only or preferably in open areas (Zone A); black is for species which can be found in two or more of these categories with none exceeding $60 \%$ (generalist species). Three classes of characters-temporality, habitat specificity and abundance in each zone-were used to build this figure. We assumed that species placed on the center of the spiral are the most specialized (Baronia brevicornis) while those on the periphery (Eurema daira and Pyrisitia proterpia) are the most generalist species.

\subsection{Comparison of the Two Analyses}

For the rainy season (Table A2), 5.4\% (5 out of 93) of the butterflies, were not congruent between theoretical cladistics and SOM analyses of occurrences. This percentage was $16.7 \%$ (7 species out of 42$)$ for dry season (Table A3).

During the rainy season (Table A2), $46.24 \%$ of the species (43 out of 93) tended to occupy only one type of habitat and could therefore be considered relevant bioindicators. Zone A had 7 out of 13 specific species (54\%), Zones B and C had 4 out of $15(27 \%)$ and Zone W had 6 out of $15(40 \%)$. For the dry season (Table A3), we found $26 \%$ species (11 out of 42 ) in just one type of habitat, and only a single bioindicator of Zone A ( 1 out of $9,11 \%$ ) and W (1 out of $2,50 \%)$.

\section{Discussion}

The main aim of our study was to examine the potential of butterfly communities as bioindicators to assess different states of TDF regeneration. Specifically, we expected the community of Lepidoptera after 20-30 years without anthropogenic action to converge towards that of the control primary TDF (Zone W). Given that adults are usually easier to identify than caterpillars, students in biology and environmental managers of different sites could easily use butterflies to routinely evaluate restoration states. This approach has some limitations, especially when the number of insects is low. However, a study of North American butterflies, with a sampling limited to around 30 species $[59,60]$ showed that a general linear model allowed samples of less than $10 \%$ of the total number of species to explain $77-88 \%$ of the variation in the species richness at a local scale. 


\subsection{Specificity of Lepidoptera Habitat}

Some Lepidoptera species have been shown to possess high habitat specificity $[35,54,61]$ and can be used as bioindicators [40]. Checking the congruence between the theoretical occurrence and the crude results of presence (SOM analysis), we obtained (regardless of the season) around $49 \%$ of Lepidoptera species specific for a type of habitat. In a very distinct context, but to illustrate the habitat specificity of imagos, a former study performed in the Mediterranean eastern part of the Pyrenees (France) found that $36 \%$ of species were considered to be relevant [41].

During the rainy season, species with the highest level of specificity occurred in open fields (Zone A): Eurema daira [Pieridae], Danaus eresimus, Danaus plexippus, Danaus gilipus, Euptoieta claudia, Anartia fatima and Anartia jatrophae (Nymphalidae). Six species were specific for the reference forest (Zone W), namely Hamadryas glauconone (Nymphalidae), Astraptes fulgerator, Heliopetes laviana, Synapte syraces, Synapte pecta and Piruna purepecha (Hesperiidae). Finally, the species specific for shrubby areas (Zone B and C) were Baronia brevicornis (Papilionidae), Siproeta stelenes (Nymphalidae), Emesis emesia, and Cyanophrys miserabilis (Lycaenidae).

For the dry season, the main indicator species in open-field areas was Nathalis iole and for forest, it was Eurema daira (Pieridae). Concerning this last species, it is very interesting to note that its classification as a full generalist species has to be drastically modified as we realized that it is a specialized taxon depending on season (open field for rain season/conserved-closed forest for dry season). A seasonal migration occurs which was already observed and suggested by some authors $[43,62,63]$.

Some trends in family characteristics appear to be present. Pieridae were more often observed in open habitats including semi-desert and arid grasslands [64] and many Nymphalidae were seen in dry or mesophilic areas basking with their wings wide open [65]. Hesperiidae are considered indicators of the richness and uniqueness of a habitat [66]. Papilionidae were commonly seen in grasslands, plains and hills (even though some, such as Troidini, are specialized for humid forest) [65]. No clear trends were found for Lycaenidae, but we did notice that most of the Theclinae were good markers of conserved forests, while Polyommatinae were mostly from open fields. The subfamily Riodininae (considered to be a distinct family for many authors) was much more diverse with species specialized in various environments.

\subsection{Lepidoptera as Bioindicators}

Our study showed that Lepidoptera were sensitive to temporal variations in humidity, which was especially evident from the difference between the two seasons, and they had a differential response to the environmental changes. For the data analyses, it was necessary to separate the two seasons of dry tropical forest $[7,49]$. Our monthly sampling during two successive years took into account the seasonal variation in the density of butterflies which was more relevant in the rainy season. Considering that our four study sites were geographically in close proximity, it is possible that some individuals migrated between them. This could explain some similarities between some of our calculated diversity indices.

The case of the genus Pyrgus was especially interesting. The three species seem to be present everywhere, mainly because they look very similar, especially when in flight, which makes identification difficult. However, it was rare to observe two of these species flying together. An important point is that the Pyrgus species feed on the same widespread and common plants (Malvaceae, Sphaeralcea sp. or Sida sp. $[43,67])$. These three species of the same genus can be compared to those of the European Pyronia sp. for which, in a former study [41], we found a very clear specificity of habitat depending on species sharing the same host plant. This illustrate a competition/exclusion process between close species of the same genus. 


\subsection{Diversity of the Successional Stages}

The estimation of species richness using the Chao1 index (Table 2) was congruent with the observed richness for the dry season. For the rainy season, a slight but non-significant undervaluation of the sampling, when compared to the Chao1 index and $\alpha$-diversity, was noticed (especially for Zone A).

The native fauna of the TDF (mainly of Zone W) disappeared or at least were disturbed and a new, so-called "anthropomorphic" or "synanthropic" combination of species replaced the local and specialized fauna. This phenomenon was already described in various studies of butterflies or other arthropods $[41,47,68-71]$. It was already noted that, during the passive regeneration of TDFs after human activities ceased, a low diversity of plants with very high densities was observed for early successional stages (Zone A) and that for the most developed stages (Zones B, C and W), a larger diversity of plant families and species occurred but with much lower densities [68,72].

Zone A was unexpectedly diverse, which could be explained by the occurrence of two types of species, the true specialists of open fields and generalist species. Most generalist species prefer open fields created by human activities, which are areas more easily colonized by less specialized species [44-46,50]. The transitional state, i.e., the shrub environment (Zones B and C), exhibited a higher proportion of habitat specialists than other sites $(73.81 \%$ in dry season and $53.76 \%$ in rainy season). Most of the species found in the conserved forest (Zone W) were absent from all the other zones demonstrating a high specificity and the important role of the habitat characteristics in terms of herbaceous layer in controlling Lepidoptera community assemblage [73]. A main finding of this study is that almost no species from Zone $\mathrm{W}$ were present in the most mature (25 years) zone of our sampling.

When comparing $\beta$-diversity values, a decrease of observable imagos was the main factor of change between the rainy (greater number of visible species) and dry season (lower number) while replacement of species between communities was the main factor of change observed between studied sites independent of the season.

\subsection{Passive Regeneration of the Dry Tropical Forest}

Ecosystem resilience [74] is the ability to return to a stable state following disturbance. Monitoring the effects of restoration on the ecosystem can easily be performed through insects because their populations depend on the plants that grow in that zone $[36,37,39]$. In our study, even though no replication of zones within age classes across the landscape were possible to perform, 25 years of passive restoration was not sufficient to reach a totally restored TDF, comparable to the reference Zone W. Resilience (and passive regeneration) of the dry tropical forest seemed to be extremely variable depending on local conditions. Madagascar has shown a fast regeneration capacity (around 10 years) [75], while other studies have found that a minimum of 25 years (but mostly up to 50 years) was necessary [76-78]. Recently, it was considered that the time of plant community recovery in terms of biomass, species richness and structural composition ranges from 30 to 50 years [79], but when precipitation is less than $1000 \mathrm{~mm}$ per year, this time range may increase to 80 years $[27,80]$. In our study, a single butterfly species (Myscelia cyananthe) was found to be equally common in Zones C and $\mathrm{W}$, showing a possible starting point to original climax. However, in the specific case of the Mexican TDF, we observed that the stable and natural vegetation state can be similar to the one observed in Zone C. Such breakpoints during succession result in almost pure acacia settlements (locally called "cubateras") and represent the biotope for ultra-specialized species such as the Mexican endemic Baronia brevicornis [14,81].

Up to now, such breakpoints in succession have not been clearly explained, but they are certainly caused by several factors such as the local soil pedology, geology, topography, availability of water and possibly allelopathic effects due to secondary metabolites produced by the roots of Mimosoideae. The slow passive regeneration of TDF compared to humid tropical forests [24,82] may be due to its high average temperature and low precipitation. As previously mentioned, with only $2 \%$ of intact forest and $8 \%$ legally protected, the TDF is probably (with the cloud forest) the most endangered ecosystem 
in the world and has to be prioritized in terms of management and conservation effort $[8,10,26,79]$. Lepidoptera showed sufficient resilience which should be considered as a good marker of passive regeneration (and restoration) in the context of the Mexican tropical dry forest, which was also found in temperate areas [41,44-47]. Despite the limitations inherent to biodiversity records in remote locations, our dataset is substantial with more than 5000 butterflies counted. Even though our study needs more replicates to secure our conclusions, it seems that plants, which are a classical bioindicator, are following a similar succession and recovery rate in the Mexican TDFs (Dorado and Jesus-Almonte, unpublished results). A similar observation applies to some Coleoptera families (Toledo-Hernandez and Corona-Lopez for Cerambycidae, unpublished results). In future work, a meta-analysis of various group of easily observable organisms could therefore be relevant to demonstrate convergent patterns among coexisting taxa (including the Lepidoptera considered in our work) with the aim to bring out efficient surrogate taxa for the survey of TDF status and recovery.

Author Contributions: L.L. and O.D. conceived the research; L.L. and J.M.d.J.-A. performed field work; L.L., M.V., K.L., R.C. analyzed the data; L.L., M.V., K.L., R.C. wrote and edited the manuscript. All authors have read and agreed to the published version of the manuscript.

Funding: This research received no external funding.

Acknowledgments: Many thanks to all those who helped us in the field, including many students of the University of Morelos (Universidad Autónoma del Estado de Morelos, UAEM), and farmers living in the REBIOSH. Special thanks to Víctor Toledo Hernández who provided us local authorisations under the authority of the SEMARNAT FAUT-0178 (Secretaría de Medio Ambiente y Recursos Naturales) permit. Kalina Bermudez-Torres is thanked for her critical assessment of early versions of this manuscript and all the valuable information provided on the structure and dynamics of the Mexican tropical dry forest. Finally, thanks to Ben-Erik Van Wyk from Johannesburg University (South Africa) to carefully check English of this manuscript.

Conflicts of Interest: One of us (LL) is section editor in chief of this journal.

\section{Appendix A}

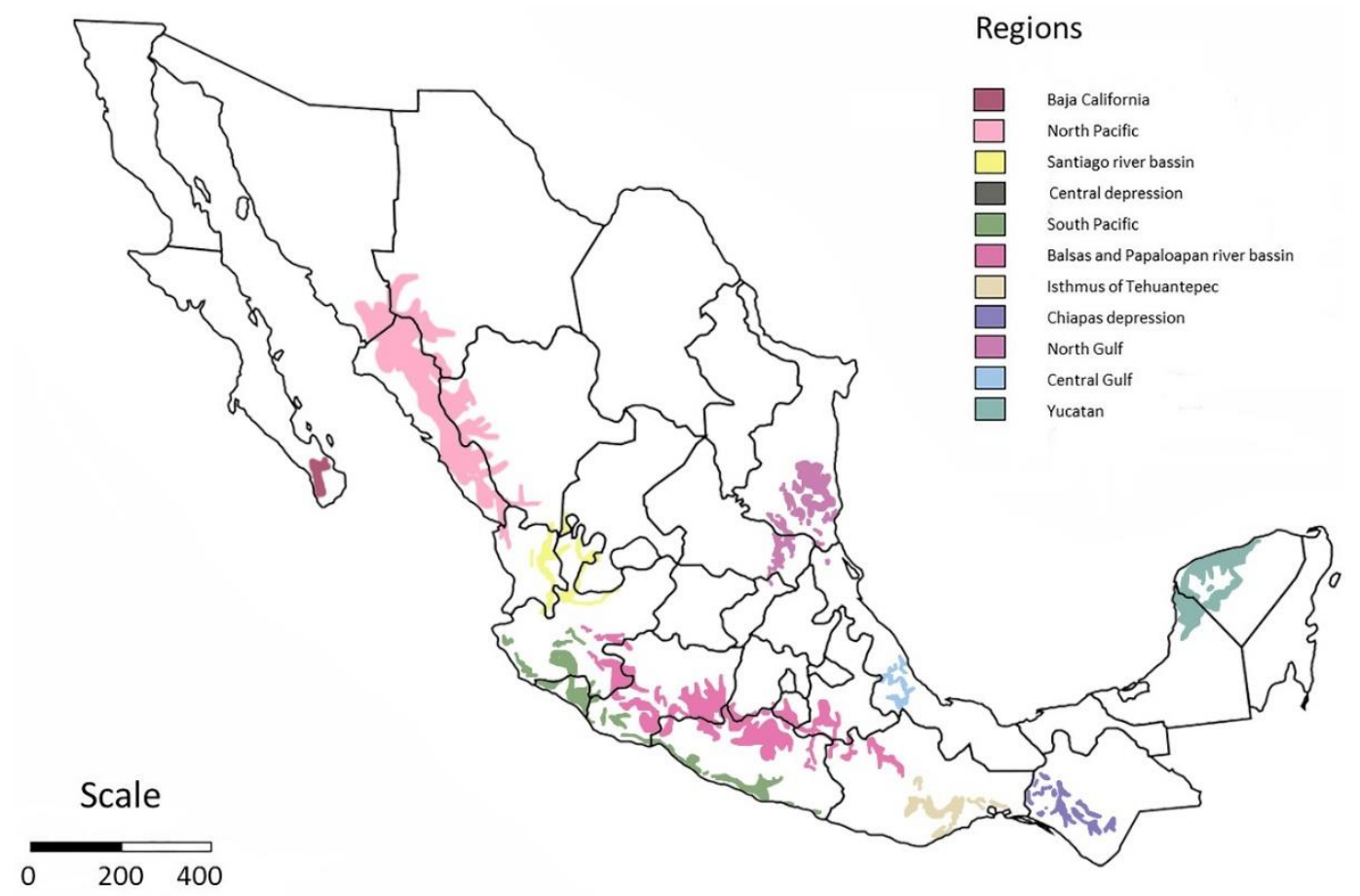

Figure A1. Main subdivisions of the tropical dry forest of Mexico according to [26]. Scale in km. 


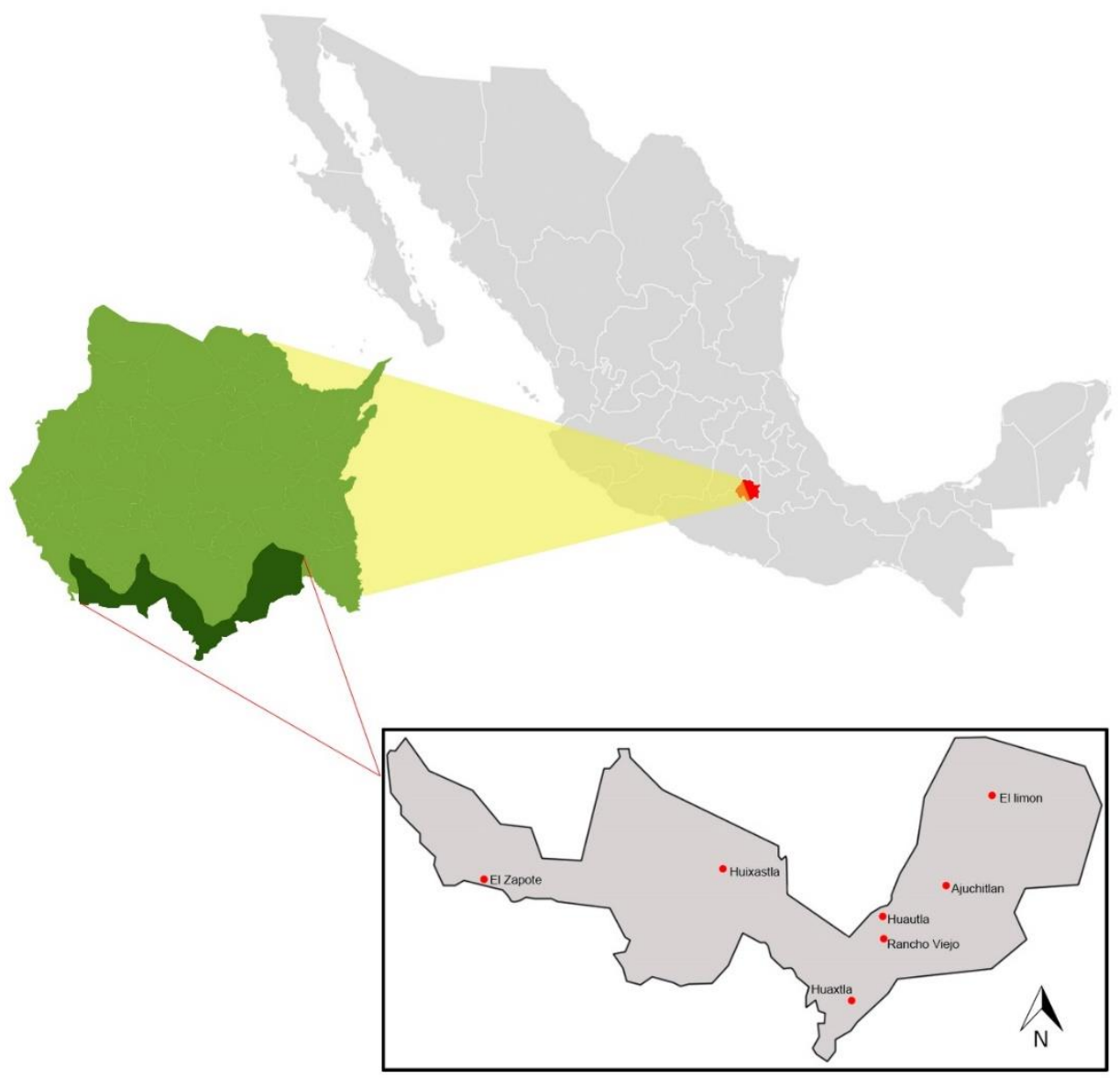

Figure A2. Location of REBIOSH in Mexico (Biosphere reserve of the Sierra de Huautla, Morelos State).

Table A1. Complete list of Lepidoptera collected during this study, including their distributions. Note that descriptions correspond to the local subspecies [64] including the name change of Papilio cresphontes for Papilio rumiko (see description of this species). Highlighted in gray are the species with only a few individuals sampled, which were excluded from statistical analyses.

\begin{tabular}{|c|c|c|c|c|c|}
\hline Family & Subfamily & Genus & Species & Description & Distribution \\
\hline \multirow[t]{5}{*}{ Papilionidae } & \multirow{3}{*}{$\begin{array}{l}\text { Baroniinae } \\
\text { Papilioninae } \\
\text { Troidini }\end{array}$} & Baronia & brevicornis & Salvin, 1893 & W Mexico \\
\hline & & & & & \\
\hline & & Parides & photinus & Doubleday, 1844 & Mexico to Costa Rica \\
\hline & \multirow{2}{*}{$\begin{array}{l}\text { Leptocircini } \\
\text { Papilionini }\end{array}$} & Eurytides & epidaus & Salvin and Godman, 1868 & W. Mexico \\
\hline & & Papilio & rumiko & Shiraiwa and Grishin, 2014 & S USA to Panama \\
\hline \multirow[t]{10}{*}{ Pieridae } & \multirow[t]{10}{*}{ Coliadinae } & Abaeis & nicippe & Cramer, 1779 & S USA to Costa Rica \\
\hline & & Eurema & boisduvaliana & Felder and Felder, 1865 & S USA to Costa Rica \\
\hline & & Eurema & daira & Felder, 1869 & S USA to W Mexico \\
\hline & & Eurema & mexicana & Boisduval, 1836 & S USA to Panama \\
\hline & & Nathalis & iole & Boisduval, 1836 & Canada to Honduras \\
\hline & & Pyrisitia & dina & Boisduval, 1836 & S USA to Panama \\
\hline & & Pyrisitia & lisa & Herrich-Schäffer, 1865 & S USA to Panama \\
\hline & & Pyrisitia & nise & Felder, 1869 & S USA to Panama \\
\hline & & Pyrisitia & proterpia & Fabricius, 1775 & S USA to Peru \\
\hline & & Zerene & cesonia & Stoll, 1790 & S USA to Colombia \\
\hline
\end{tabular}


Table A1. Cont.

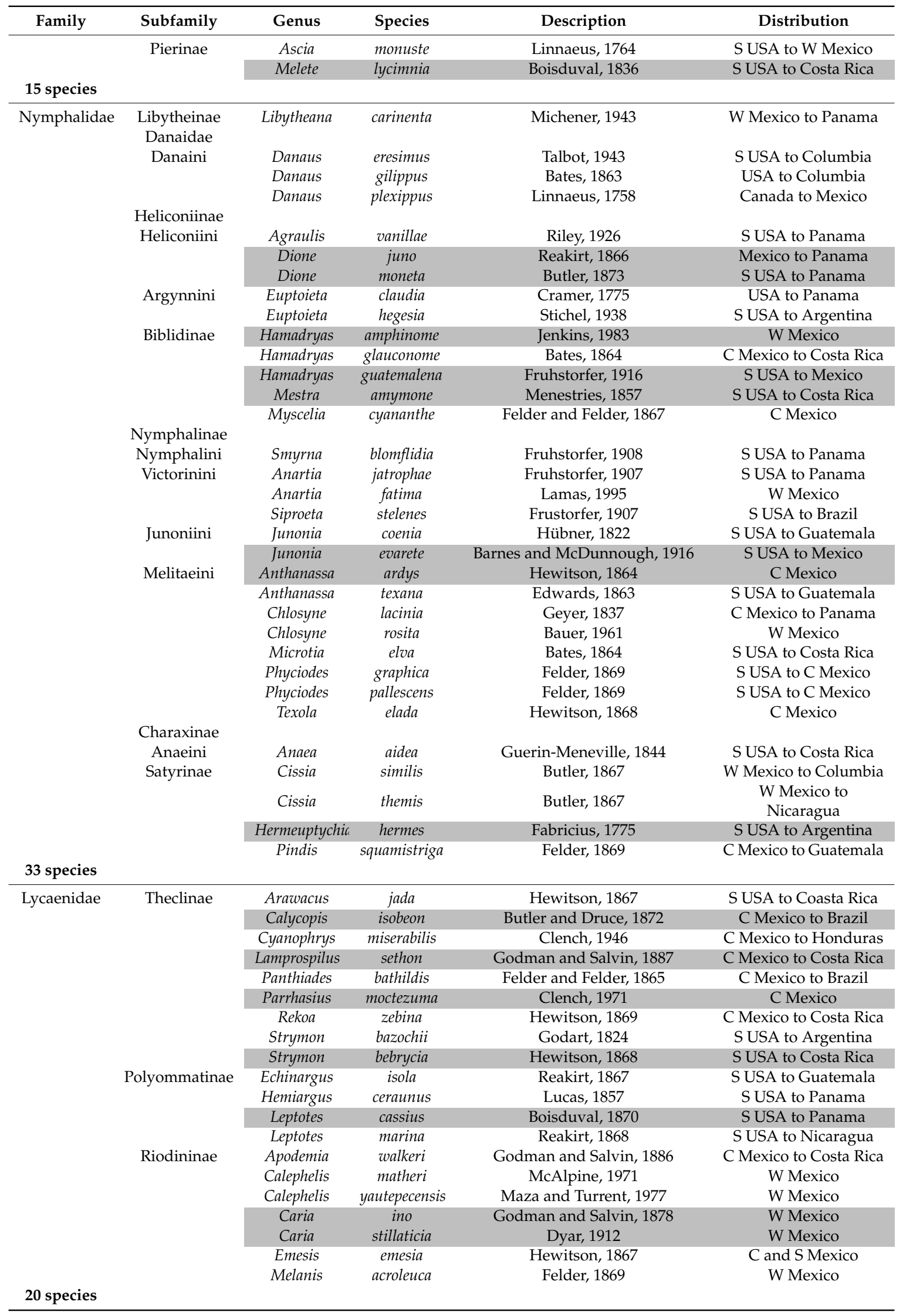


Table A1. Cont.

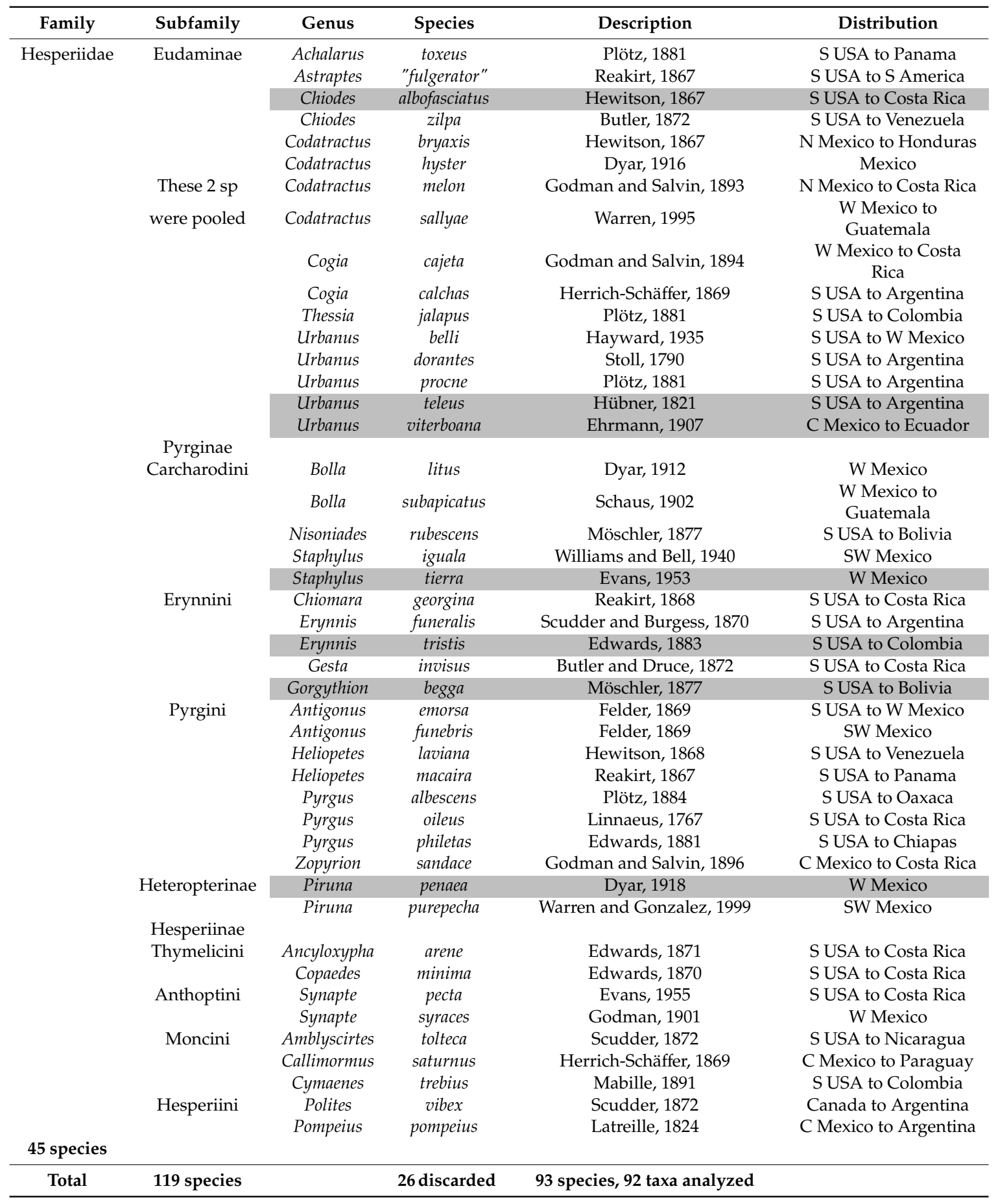


Table A2. Theoretical versus observed distributions (SOM analysis) of the 93 species sampled in the rainy season. "G" is generalist species and " $\mathrm{S}$ " is specialist species. Degree of openness: " $\mathrm{A}$ " is open, $\mathrm{B}$ and $\mathrm{C}$ are shrubs and $\mathrm{W}$ is trees. Humidity gradient: ${ }^{*}$ is xeric, ${ }^{* *}$ moderately xeric, ${ }^{* * *}$ is humid. Evaluation of the congruence: $\mathrm{Y}$ (yes): $51 / 93$ species ( $54.8 \%$ ); $\mathrm{N}$ (no): $5 / 93$ species ( $5.4 \%$ ); 0 : compatible but not positive or negative. Tendency: congruence not at $100 \%$. Bold species are considered bioindicators. Note: some generic names were abbreviated to fit the table.

\begin{tabular}{|c|c|c|c|c|c|c|}
\hline \multirow[b]{2}{*}{ Species } & \multicolumn{3}{|c|}{ Theoretical } & \multicolumn{3}{|c|}{ SOM Result Observed } \\
\hline & $\begin{array}{l}\text { Degree of } \\
\text { Openness }\end{array}$ & $\begin{array}{l}\text { Humidity } \\
\text { Gradient }\end{array}$ & G or $S$ & $\begin{array}{l}\text { Degree of } \\
\text { Openness }\end{array}$ & $\begin{array}{c}\text { Humidity } \\
\text { Gradient }\end{array}$ & Congruence \\
\hline B.brevicornis & Shrubs & $*$ & $\mathbf{S}$ & Shrubs & $*$ & $\mathbf{Y}$ \\
\hline Papilio rumiko & Open-Shrubs & ** & G & Shrubs & ** & Tendency \\
\hline Eurytides epidaus & Shrubs & $*$ & G & Shrubs & * & $\mathrm{Y}$ \\
\hline Ascia monuste & Open & $* *$ & G & Open & $* *$ & $\mathrm{Y}$ \\
\hline Abaeis nicippe & Shrubs & $*$ & G & Open & $* *$ & 0 \\
\hline Eurema arbella & Trees & $* * *$ & $S$ & Trees & $* *$ & Tendency \\
\hline Eurema daira & Open & * & $\mathbf{S}$ & Open & $* *$ & Tendency \\
\hline Eurema mexicana & Open-Shrubs & $* *$ & G & Open & $* *$ & $\mathrm{Y}$ \\
\hline Nathalis iole & Open-Shrubs & $* *$ & G & Open & * & 0 \\
\hline Phoebis agarithe & Open & $* *$ & G & Open & $*$ & Tendency \\
\hline Phoebis philea & Trees & $* * *$ & G & Trees & $* * *$ & $\mathrm{Y}$ \\
\hline Phoebis sennae & Shrubs-Trees & $* *$ & G & Trees & $* *$ & Y \\
\hline Pyrisitia dina & Shrubs & $* *$ & G & Shrubs & $* *$ & $\mathrm{Y}$ \\
\hline Pyrisitia lisa & Open-Shrubs & $* *$ & G & Open & $* * *$ & Tendency \\
\hline Pyrisitia nise & Shrubs & $* *$ & G & Shrubs & $* *$ & $\mathrm{Y}$ \\
\hline Pyrisitia proterpia & Shrubs & $* *$ & G & Shrubs & $* * *$ & Tendency \\
\hline Zerene cesonia & Open-Shrubs & $* *$ & G & Open-Shrubs & $* *$ & $\mathrm{Y}$ \\
\hline L.carinenta & Shrubs-Trees & $*$ & G & Shrubs & $* *$ & Tendency \\
\hline D.eresimus & Open & * & $\mathbf{S}$ & Open & * & $\mathbf{Y}$ \\
\hline D.plexippus & Open & ** & $\mathrm{S}$ & Open & * & $\mathbf{Y}$ \\
\hline Danaus gillipus & Open & * & $\mathrm{S}$ & Open & * & $\mathbf{Y}$ \\
\hline Agraulis vanillae & Open-shrub & $* *$ & G & Open & $* *$ & $\mathrm{Y}$ \\
\hline E. claudia & Open & $* *$ & $\mathbf{S}$ & Open & $* *$ & $\mathbf{Y}$ \\
\hline Euptoieta hegesia & Open & $* *$ & $S$ & Open-Shrubs & $* *$ & $\mathrm{Y}$ \\
\hline H. glaucomone & Trees & $* * *$ & $\mathrm{~S}$ & Trees & $* * *$ & $\mathbf{Y}$ \\
\hline M.cyananthe & Trees & $* * *$ & G & Trees & $* * *$ & $\mathrm{Y}$ \\
\hline S. steneles & Shrubs & $* * *$ & $\mathbf{S}$ & Shrubs & $* * *$ & $\mathbf{Y}$ \\
\hline Smyrna blonfildia & Trees & $* * *$ & $\mathrm{G}$ & Trees & $* * *$ & $\mathrm{Y}$ \\
\hline Anartia fatima & Open & $* *$ & $\mathrm{~S}$ & Open & ** & $\mathbf{Y}$ \\
\hline $\begin{array}{c}\text { Anartia } \\
\text { jatrophae }\end{array}$ & Open & $* *$ & $\mathbf{S}$ & Open & $* *$ & $\mathbf{Y}$ \\
\hline A.texana & Shrubs & $* *$ & G & Shrubs & $* *$ & $\mathrm{Y}$ \\
\hline Chlosyne lacinia & Open-Shrubs & $* *$ & G & Shrubs & $* * *$ & Tendency \\
\hline Chlosyne rosita & Generalist & $* * *$ & G & Generalist & $* *$ & Tendency \\
\hline Junonia coenia & Open & $* *$ & G & Open & $*$ & Tendency \\
\hline Microtia elva & Trees & $* * *$ & G & Trees & $* * *$ & $\mathrm{Y}$ \\
\hline P.graphica & Trees & $* *$ & G & Open-Shrubs & $* *$ & Tendency \\
\hline P.pallescens & Open & $* *$ & G & Open-Shrubs & $* *$ & $\mathrm{Y}$ \\
\hline Texola elada & Shrubs-Trees & $* *$ & G & Trees & $* *$ & Y \\
\hline Anaea aidea & Shrubs & $* *$ & G & Shrubs & $* * *$ & Tendency \\
\hline Cissia similis & Trees & $* *$ & G & Trees & $* *$ & $\mathrm{Y}$ \\
\hline Cissia themis & Shrubs-Trees & $* * *$ & G & Trees & $* *$ & Tendency \\
\hline P.squamistriga & Open-Shrubs & $* *$ & G & Open-Shrubs & $* *$ & $\mathrm{Y}$ \\
\hline Apodemia walkeri & Open-Shrubs & $* *$ & G & Shrubs & $* * *$ & Tendency \\
\hline C.matheri & Open & $*$ & G & Open & $* *$ & Tendency \\
\hline C.yautepequensis & Open & $*$ & G & Open & $*$ & $\mathrm{Y}$ \\
\hline
\end{tabular}


Table A2. Cont.

\begin{tabular}{|c|c|c|c|c|c|c|}
\hline \multirow[b]{2}{*}{ Species } & \multicolumn{3}{|c|}{ Theoretical } & \multicolumn{3}{|c|}{ SOM Result Observed } \\
\hline & $\begin{array}{l}\text { Degree of } \\
\text { Openness }\end{array}$ & $\begin{array}{l}\text { Humidity } \\
\text { Gradient }\end{array}$ & G or $S$ & $\begin{array}{l}\text { Degree of } \\
\text { Openness }\end{array}$ & $\begin{array}{l}\text { Humidity } \\
\text { Gradient }\end{array}$ & Congruence \\
\hline Emesis emesia & Shrubs & $* *$ & $\mathbf{S}$ & Shrubs & $* *$ & $\mathbf{Y}$ \\
\hline Melanis acroleuca & Shrubs & $* * *$ & $\mathrm{G}$ & Shrubs & $* * *$ & $\bar{Y}$ \\
\hline H.ceraunus & Open-Shrubs & $* *$ & G & Open & $*$ & 0 \\
\hline Hemiargus isola & Open & $* * *$ & $\mathrm{G}$ & Shrubs & $* *$ & $\mathrm{~N}$ \\
\hline Leptotes marina & Open-Shrubs & $* *$ & G & Open & $* *$ & Y \\
\hline Arawacus jada & Shrubs & $* *$ & $S$ & Open & $* *$ & Tendency \\
\hline C.miserabilis & Shrubs & $* *$ & $\mathbf{S}$ & Shrubs & $* *$ & $\mathrm{Y}$ \\
\hline P.bathildis & Trees & $* * *$ & $\mathrm{G}$ & Trees & $* * *$ & $\mathrm{Y}$ \\
\hline Rekoa zebina & Shrubs & $* * *$ & G & Shrubs & $* * *$ & $\mathrm{Y}$ \\
\hline Strymon bazochii & Shrubs & $* *$ & G & Open & $* *$ & Tendency \\
\hline Achalarus toxeus & Open-Shrubs & $* *$ & G & Trees & $* *$ & Tendency \\
\hline A.fulgerator & Trees & $* * *$ & $\mathbf{S}$ & Trees & $* * *$ & $\mathrm{Y}$ \\
\hline Chioides zilpa & Open-Shrubs & $* *$ & G & Trees & ** & Tendency \\
\hline C.bryaxis & Trees & $* * *$ & G & Shrubs & $* * *$ & Tendency \\
\hline C.hyster & Shrubs & $* *$ & G & Shrubs-Trees & $* * *$ & Tendency \\
\hline C.melon/sallyae & Shrubs & $* * *$ & $\mathrm{G}$ & Shrubs & $* * *$ & $\mathrm{Y}$ \\
\hline Cogia cajeta & Open-Shrubs & $*$ & G & Shrubs & $* *$ & 0 \\
\hline Cogia calchas & Shrubs & $* *$ & G & Shrubs & $* *$ & $\mathrm{Y}$ \\
\hline Thessia jalapus & Shrubs & $* *$ & G & Open & $*$ & 0 \\
\hline Urbanus belli & Trees & $* *$ & G & Shrubs & $* *$ & Tendency \\
\hline Urbanus dorantes & Shrubs & $* *$ & G & Shrubs & $* * *$ & Tendency \\
\hline Urbanus procne & Open-Shrubs & $* *$ & G & Open-Shrubs & $* *$ & $\mathrm{Y}$ \\
\hline Antigonus emorsa & Open-Shrubs & $*$ & $\mathrm{G}$ & Shrubs-Trees & $* * *$ & $\mathrm{~N}$ \\
\hline A.funebris & Shrubs & $* *$ & G & Shrubs & $* * *$ & Tendency \\
\hline Bolla litus & Open-Shrubs & $* *$ & G & Open-Shrubs & $* *$ & $\mathrm{Y}$ \\
\hline Bolla subapicatus & Shrubs & $* *$ & G & Shrubs & $* *$ & $\mathrm{Y}$ \\
\hline C.georgina & Open-Shrubs & $* *$ & G & Shrubs & $* * *$ & Y \\
\hline Erynnis funeralis & Open & $* *$ & G & Open-Trees & $* *$ & $\mathrm{Y}$ \\
\hline Gesta invisus & Open-Shrubs & $* *$ & G & Trees & $*$ & 0 \\
\hline H.laviana & Trees & $* * *$ & $\mathbf{S}$ & Trees & $* * *$ & $\mathbf{Y}$ \\
\hline H.macaira & Open & $*$ & $\mathrm{G}$ & Open & $*$ & $\bar{Y}$ \\
\hline N.rubescens & Shrubs-Trees & $* *$ & $\mathrm{G}$ & Shrubs-Trees & ** & $\mathrm{Y}$ \\
\hline Pyrgus communis & Open & $*$ & G & Open-Shrubs & $*$ & Y \\
\hline Pyrgus oileus & Open & $* *$ & $\mathrm{G}$ & Trees & $* *$ & 0 \\
\hline Pyrgus philetas & Open & $* *$ & G & Open-Shrubs & $* *$ & Y \\
\hline Staphylus iguala & Shrubs-Trees & $* *$ & G & Shrubs-Trees & $* * *$ & $\mathrm{Y}$ \\
\hline Zopyrion sandace & Trees & $* *$ & G & Trees & $* * *$ & Tendency \\
\hline C.minima & Open & $* *$ & G & Shrubs & $* * *$ & $\mathrm{~N}$ \\
\hline A.tolteca & Open-Shrubs & $*$ & G & Shrubs & $* *$ & Tendency \\
\hline A.arene & Open-Shrubs & $* *$ & G & Open-Shrubs & $* *$ & $\mathrm{Y}$ \\
\hline C.saturnus & Trees & $* * *$ & G & Trees & $* * *$ & $\mathrm{Y}$ \\
\hline Cymaenes trebius & Shrubs & $* * *$ & G & Trees & $* * *$ & Tendency \\
\hline C.tripunctus & Shrubs & $* *$ & G & Open & $* *$ & Tendency \\
\hline Polites vibex & Open & $*$ & G & Open & $* *$ & Tendency \\
\hline P.pompeius & Generalist & $* *$ & G & Generalist & $* * *$ & Tendency \\
\hline Synapte syraces & Trees & $* * *$ & $\mathbf{S}$ & Trees & $* * *$ & $\mathrm{Y}$ \\
\hline Synapte pecta & Trees & $* * *$ & $\mathbf{S}$ & Trees & $* * *$ & $\mathbf{Y}$ \\
\hline P.purepecha & Shrubs-Trees & $* * *$ & $\mathbf{S}$ & Trees & $* * *$ & $\mathbf{Y}$ \\
\hline
\end{tabular}


Table A3. Theoretical versus observed distributions (SOM analysis) of the 42 species sampled in the dry season. "G" is generalist species and "S" is specialist species. Evaluation of the congruence: Y: $14 / 42$ species (33.3\%); N: 7/42 species (16.7\%); 0: compatible but not positive or negative, Tendency: congruence not at $100 \%$. Bold species are considered bioindicators. Note: some generic names were abbreviated to fit the table.

\begin{tabular}{|c|c|c|c|c|c|c|}
\hline \multirow[b]{2}{*}{ Species } & \multicolumn{3}{|c|}{ Theoretical } & \multicolumn{3}{|c|}{ SOM Result Observed } \\
\hline & $\begin{array}{l}\text { Degree of } \\
\text { Openness }\end{array}$ & $\begin{array}{l}\text { Humidity } \\
\text { Gradient }\end{array}$ & G or $S$ & $\begin{array}{l}\text { Degree of } \\
\text { Openness }\end{array}$ & $\begin{array}{l}\text { Humidity } \\
\text { Gradient }\end{array}$ & Congruence \\
\hline Abaeis nicippe & Shrubs & $* *$ & G & Open & $*$ & $\mathrm{~N}$ \\
\hline Eurema daira & Trees & $* * *$ & $\mathbf{S}$ & Trees & $* * *$ & $\mathbf{Y}$ \\
\hline E.mexicana & Open-Shrubs & $* * *$ & $\mathrm{G}$ & Open & $* * *$ & $\bar{Y}$ \\
\hline Nathalis iole & Open-Shrubs & $*$ & $\mathbf{S}$ & Open & $*$ & $\mathbf{Y}$ \\
\hline Phoebis agarithe & Open & $* *$ & $\mathrm{G}$ & Open & $*$ & Tendency \\
\hline Phoebis philea & Trees & $* * *$ & G & Trees & $* * *$ & $\mathrm{Y}$ \\
\hline Phoebis sennae & Open-Shrubs & $* * *$ & G & Open & $* * *$ & $\mathrm{Y}$ \\
\hline Pyrisitia dina & Shrubs & $* *$ & G & Shrubs-Trees & $* *$ & $\mathrm{Y}$ \\
\hline Pyrisitia nise & Shrubs & $* *$ & G & Shrubs & $* * *$ & Tendency \\
\hline Pyrisitia proterpia & Shrubs & $* *$ & G & Trees & $* * *$ & 0 \\
\hline Zerene cesonia & Open-Shrubs & $* *$ & G & Shrubs & $* * *$ & Tendency \\
\hline L.carinenta & Shrubs-Trees & $* *$ & G & Trees & $* * *$ & 0 \\
\hline D.plexippus & Open & $* *$ & $\mathbf{S}$ & Open & $*$ & Tendency \\
\hline Danaus gilipus & Open & $* *$ & $\mathbf{S}$ & Shrubs & $* * *$ & $\mathbf{N}$ \\
\hline M.cyananthe & Trees & $* * *$ & $\mathrm{G}$ & Trees & $* *$ & Tendency \\
\hline S.blonfildia & Trees & $* * *$ & G & Trees & $*$ & 0 \\
\hline A.texana & Shrubs & $* *$ & G & Trees & $* * *$ & 0 \\
\hline Junonia coenia & Open & $* *$ & G & Open & $* * *$ & Tendency \\
\hline Anaea aidea & Shrubs & $* * *$ & G & Shrubs & $* * *$ & $\mathrm{Y}$ \\
\hline Cissia similis & Trees & $* * *$ & $\mathbf{S}$ & Trees & $* *$ & Tendency \\
\hline Cissia themis & Shrubs & $* * *$ & $\mathrm{G}$ & Trees & $*$ & $\mathrm{~N}$ \\
\hline A.walkeri & Open-Shrubs & $* *$ & G & Open-Shrubs & $* * *$ & Tendency \\
\hline C.yautepequensis & Open & $*$ & $\mathrm{G}$ & Open & $*$ & $\mathrm{Y}$ \\
\hline H.ceraunus & Shrubs-Trees & $* *$ & G & Trees & * & 0 \\
\hline Hemiargus isola & Open & $* * *$ & $\mathrm{G}$ & Open & ** & Tendency \\
\hline Leptotes marina & Open-Shrubs & $* *$ & G & Open & $* *$ & $\mathrm{Y}$ \\
\hline Urbanus procne & Open-Shrubs & $* *$ & G & Trees & $* * *$ & $\mathrm{~N}$ \\
\hline A.emorsa & Open-Shrubs & $*$ & G & Shrubs-Trees & $*$ & Tendency \\
\hline Erynnis funeralis & Open & $* *$ & G & Open & $* *$ & $\mathrm{Y}$ \\
\hline H.laviana & Trees & $* * *$ & $\mathbf{S}$ & Shrubs-Trees & $*$ & $\mathbf{N}$ \\
\hline $\begin{array}{c}\text { Heliopetes } \\
\text { macaira }\end{array}$ & Open & $* *$ & G & Shrubs & $* * *$ & $\mathrm{~N}$ \\
\hline N.rubescens & Shrubs-Trees & $* * *$ & G & Open-Shrubs & $* *$ & 0 \\
\hline P.communis & Open-Shrubs & $*$ & G & Shrubs & $* * *$ & $\mathbf{N}$ \\
\hline Pyrgus oileus & Open-Shrubs & ** & G & Open & ** & $\mathrm{Y}$ \\
\hline Pyrgus philetas & Open & $*$ & $\mathrm{G}$ & Open & $* *$ & Tendency \\
\hline Staphylus iguala & Open-Shrubs & ** & $\mathrm{G}$ & Open & * & Tendency \\
\hline Zopyrion sandace & Trees & $*$ & G & Trees & $* *$ & Tendency \\
\hline C.minima & Open & $*$ & G & Open & $*$ & $\mathrm{Y}$ \\
\hline C.trebius & Shrubs & $* *$ & $\mathbf{S}$ & Trees & $* *$ & Tendency \\
\hline C.tripunctus & Shrubs & $* *$ & $\mathrm{G}$ & Open & $* *$ & Tendency \\
\hline Polites vibex & Open & $*$ & G & Open-Trees & $*$ & $\mathrm{Y}$ \\
\hline P.pompeius & Open-Shrubs & $* *$ & G & Open & $* *$ & $\mathrm{Y}$ \\
\hline
\end{tabular}




\section{References}

1. Miles, L.; Newton, A.C.; DeFries, R.S.; Ravilious, C.; May, I.; Bluth, S.; Kapos, V.; Gordon, E. A global overview of the conservation status of tropical dry forests. J. Biogeogr. 2006, 33, 491-505. [CrossRef]

2. Miranda, F.; Hernández-X, E. Los tipos de vegetación de México y su clasificación. Bot. Sci. 1963, 28, 29-179. [CrossRef]

3. Rzedowski, J. Vegetación de México; Limusa, N., Ed.; CONABIO (Comisión Nacional para el Conocimiento y Uso de la Biodiversidad): Mexico city, Mexico, 1978; pp. 1-505.

4. Gillespie, T.; Lipkin, B.; Sullivan, L.; Benowitz, D.; Pau, S.; Keppel, G. The rarest and least protected forests in biodiversity hotspots. Biodivers. Conserv. 2012, 21, 3597-3611. [CrossRef]

5. Dryflor. Plant diversity patterns in neotropical dry forests and their conservation implications. Science 2016, 353, 1383-1387. [CrossRef] [PubMed]

6. Devineau, J.L. Structure and dynamics of some tropophilous forests in West Africa (Ivory Coast). Thèse d'Etat, Ecologie, Environnement, Université Pierre et Marie Curie, Paris, France, 1984.

7. Janzen, D.H. Management of habitat fragments in a tropical dry forest: Growth. Ann. Mo. Bot. Gard. 1988, 75, 105-116. [CrossRef]

8. Janzen, D.H. Tropical dry forests: The most endangered major tropical ecosystem. In Biodiversity; Wilson, E.O., Ed.; National Academy Press: Washington, DC, USA, 1988; pp. 130-137.

9. Puig, H. Diversité spécifique et déforestation: L'exemple des forêts tropicales humides du Mexique. Bois For. Trop. 2001, 268, 41-55.

10. Trejo, I.; Dirzo, R. Deforestation of seasonally dry tropical forest: A national and local analysis in Mexico. Biodivers. Conserv. 2000, 94, 133-142.

11. Becerra, J.X.; Venable, D.L. Sources and Sinks of Diversification and Conservation Priorities for the Mexican Tropical Dry Forest. PLoS ONE 2008, 3, e3436. [CrossRef] [PubMed]

12. Portillo-Quintero, C.; Sanchez-Azofeifa, G.A. Extent and conservation of tropical dry forests in the Americas. Biodivers. Conserv. 2010, 143, 144-155. [CrossRef]

13. Holdridge, L.R. Life Zone Ecology; Tropical Science Center: San Jose, Costa Rica, 1967; pp. 1-206.

14. Legal, L.; Dorado, Ó.; Machkour-M’Rabet, S.; Leberger, R.; Albre, J.; Mariano, N.; Gers, C. Ecological constraints and distribution of the primitive and enigmatic endemic Mexican butterfly Baronia brevicornis (Lepidoptera: Papilionidae). Can. Entomol. 2015, 147, 71-88. [CrossRef]

15. Gentry, A.H. Patterns of diversity and floristic composition in Neotropical montane forest. In Biodiversity and Conservation of Neotropical Montane Forests; Churchill, S.P., Balslev, H., Forero, E., Luteyn, J.L., Eds.; The New York Botanical Garden: New York, NY, USA, 1995; pp. 103-126.

16. Murphy, P.G.; Lugo, A.E. Dry forests of Central America and the Caribbean. In Seasonally Dry Tropical Forests; Bullock, S.H., Mooney, H., Medina, E., Eds.; Cambridge University Press: Cambridge, UK, 1995; pp. 9-34.

17. Challenger, A.; Soberón, J. Los Ecosistemas Terrestres, en Capital Natural de México, Vol. I: Conocimiento Actual de la Biodiversidad; Conabio: Tlalpan, Mexico, 2008; pp. 1-30.

18. Center for International Forestry Research (CIFOR). Tropical Dry Forests under Threat \& Under-Researched. 2014. Available online: https://www.cifor.org/publications/pdf_files/factsheet/4875-factsheet.pdf (accessed on 27 November 2019).

19. Sabogal, C. Regeneration of tropical dry forests in Central America, with examples from Nicaragua. J. Veg. Sci. 1992, 3, 407-416. [CrossRef]

20. Martínez, H.A. El problema de la Leña en las zonas secas de América Central: Necesidades de investigación. In Técnicas de Producción en Fincas Pequeñas Y Recuperación De Sitios Degradados Por Medio de la Silvicultura; Acta de Simposio, 24-25.6.1988, Salazar, R., Eds.; CATIE: Turrialba, Costa Rica, 1985; pp. 33-45.

21. FAO State of the World's Forests. Pp 157 Rome. 2007. Available online: http://www.fao.org/3/a-a0773e.pdf (accessed on 27 November 2019).

22. Giam, X. Global biodiversity loss from tropical deforestation. PNAS 2017, 114, 5775-5777. [CrossRef] [PubMed]

23. Brown, S.; Lugo, A.E. The Storage and Production of Organic Matter in Tropical Forests and Their Role in the Global Carbon Cycle. Biotropica 1982, 14, 161-187. [CrossRef]

24. Murphy, P.G.; Lugo, A.E. Ecology of tropical dry forest. Annu. Rev. Ecol. Evol. Syst. 1986, 17, 67-88. [CrossRef] 
25. Mooney, H.A.; Bullock, S.H.; Medina, E. Introduction. In Seasonally Dry Tropical Forests; Bullock, S.H., Mooney, H.A., Medina, E., Eds.; Cambridge University Press: Cambridge, UK, 1995; pp. 9-11.

26. Trejo, I. Distribución y diversidad de selvas bajas de México: Relaciones con el clima y el suelo. Ph.D. Thesis, Universidad Nacional Autonoma De Mexico, Mexico City, Mexico, 1998.

27. Becknell, J.M.; Kissing Kucek, L.; Powers, J.S. Above ground biomass in mature and secondary seasonally dry tropical forests: A literature review and global synthesis. For. Ecol. Manag. 2012, 276, 88-95. [CrossRef]

28. Walker, L.R.; Walker, J.; Hobbs, R.J. Linking Restoration and Ecological Succession; Springer: New York, NY, USA, 2007; pp. 1-188.

29. Chazdon, R.L. Beyond deforestation: Restoring forests and ecosystem services on degraded lands. Science 2008, 320, 1458-1460. [CrossRef] [PubMed]

30. Prach, K.; Marrs, R.; Pysek, P.; van Diggelen, R. Manipulation of succession. In Linking Restoration and Ecological Succession; Walker, L.R., Walker, J., Hobbs, R.J., Eds.; Springer: New York, NY, USA, 2007; pp. 121-149.

31. Zimmerman, J.K.; Aide, T.M.; Lugo, A.E. Old Fields: Dynamics and Restoration of Abandoned Farmland; Cramer, V.A., Hobbs, R.J., Eds.; Island Press: Washington, DC, USA, 2007; pp. 51-74.

32. Martinez-Garza, C.; Osorio-Beristain, M.; Valenzuela-Galvan, D.; Nicolas-Medina, A. Intra and inter-annual variation in seed rain in a secondary dry tropical forest excluded from chronic disturbance. For. Ecol. Manag. 2011, 262, 2207-2218. [CrossRef]

33. Juan-Baeza, I.; Martinez-Garza, M.; del-Val, E. Recovering more than tree cover: Herbivores and herbivory in a tropical dry forest. PLoS ONE 2015, 10, e0128583. [CrossRef] [PubMed]

34. Solis-Gabriel, L.; Mendoza-Arroyo, W.; Boege, K.; del-Val, E. Restoring lepidopteran diversity in a tropical dry forest: Relative importance of restoration treatment, tree identity and predator pressure. PeerJ 2017, 5, e3344. [CrossRef] [PubMed]

35. Luque, C.; Gers, C.; Lauga, J.; Mariano, N.A.; Wink, M.; Legal, L. Analysis of forestry impacts and Biodiversity in two Pyrenean Forests through a Comparison of moth communities (Lepidoptera, Heterocera). Insect Sci. 2007, 14, 323-338. [CrossRef]

36. Bowman, D.M.J.S.; Woinarski, J.C.Z.; Sands, D.P.A.; Wells, A.; McShane, V. Slash-and-burn agriculture in the wet coastal lowlands of Papua New Guinea: Response of birds, butterflies and reptiles. J. Biogeogr. 1990, 7 , 227-239. [CrossRef]

37. Kimberling, D.N.; Karr, J.R.; Fore, L.S. Measuring human disturbance using terrestrial invertebrates in the shrub-steppe of eastern Washington (USA). Ecol. Indic. 2001, 1, 63-137. [CrossRef]

38. Gerlach, J.; Samways, M.; Pryke, J. Terrestrial invertebrates as bioindicators: An overview of available taxonomic groups. J. Insect Conserv. 2013, 17, 831-850. [CrossRef]

39. Paoletti, M.G. Practical use of invertebrates to assess sustainable land use. Agric. Ecosyst. Environ. 1999, 74, 9-11.

40. Oostermeijer, J.G.B.; van Swaay, C.A.M. The relationship between butterflies and environmental indicator values: A tool for conservation in a changing landscape. Biol. Conserv. 1998, 86, 271-280. [CrossRef]

41. Ricouart, F.; Céréghino, R.; Gers, C.; Winterton, P.; Legal, L. Influence of fire prevention management strategies on the diversity of butterfly fauna in the eastern Pyrenees. J. Insect Conserv. 2013, 17, 95-111. [CrossRef]

42. Raguso, R.A.; Llorente-Bousquets, J. The butterflies (Lepidoptera) of the Tuxtlas Mts., Veracruz, Mexico, revisited: Species-richness and habitat disturbance. J. Res. Lepid. 1990, 29, 105-133.

43. Legal, L.; Dorado, Ó.; Albre, J.; Bermudez-Torres, K.; Lopez, K. Mariposas diurnas, Reserva de la Biosfera Sierra de Huautla, Estado de Morelos, México; Trópico Seco Ediciónes: Cuernavaca, Morelos, Mexico, 2017; p. 330.

44. Inoue, $\mathrm{T}$. Chronosequential change in a butterfly community after clear-cutting of deciduous forests in a cool temperate region of central Japan. Entomol. Sci. 2003, 6, 151-163. [CrossRef]

45. Viljur, M.L.; Teder, T. Butterflies take advantage of contemporary forestry: Clear-cuts as temporary grasslands. For. Ecol. Manag. 2016, 376, 118-125. [CrossRef]

46. Riva, F.; Acorn, J.H.; Nielsen, S.E. Localized disturbances from oil sands developments increase butterfly diversity and abundance in Alberta's boreal forests. Biol. Conserv. 2018, 217, 173-180. [CrossRef]

47. Rosin, Z.M.; Myczko, L.; Skorka, P.; Lenda, M.; Moron, D.; Sparks, T.H.; Tryjanowski, P. Butterfly responses to environmental factors in fragmented calcareous grasslands. J. Insect Conserv. 2011, 16, 321-329. [CrossRef] 
48. Davidar, P.; Devy, S.; Yoganand, T.; Ganesh, T. Reserve size implications for the conservation of biodiversity in the Andaman Islands. In Measuring and Monitoring Biodiversity in Tropical and Temperate Forests; Boyle, T.J.B., Boontawee, B., Eds.; Centre for International Forestry Research: Bogor, Indonesia, 1995; pp. 287-301.

49. Hill, C.S. The temporal distribution of butterfly species richness in a subtropical region of Australia. Proc. Ecol. Soc. Aus. 1988, 15, 115-126.

50. Lawton, J.H.; Bignell, D.E.; Bolton, B.; Bloemers, G.F.; Eggleton, P.; Hammond, P.M.; Watt, A.D. Biodiversity inventories, indicator taxa and effects of habitat modification in tropical forest. Nature 1998, 391, 72-76. [CrossRef]

51. Rueda, R. Atlas Municipal del Estado de Morelos; Universidad Autónoma del Estado de Morelos: Cuernavaca, Mexico, 2006; pp. 1-396.

52. Torres, C.; Osorio-Beristain, M.; Mariano, N.; Legal, L. Sex-dependant seasonal activity patterns among two subfamilies of Nymphalidae (Lepidoptera) in the Mexican tropical dry forest. Ann. Soc. Entomol. Fr. 2009, 45, 265-274. [CrossRef]

53. Chao, A. Non-parametric estimation of the number of classes in a population. Scand. J. Stat. 1984, 11, 265-270.

54. Luque, C.; Legal, L.; Winterton, P.; Mariano, N.A.; Gers, C. Illustration of the Structure of Arthropod Assemblages (Collembola and Lepidoptera) in Different Forest Types: An Example in the French Pyrenees. Diversity 2011, 3, 693-711. [CrossRef]

55. Carvalho, J.C.; Cardoso, P.; Gomes, P. Determining the relative roles of species replacement and species richness differences in generating beta-diversity patterns. Glob. Ecol. Biogeogr. 2012, 21, 760-771. [CrossRef]

56. Kohonen, T. Self-Organizing Maps, 3th ed.; Springer: Berlin, Germany, 2001; pp. 1-371.

57. Céréghino, R.; Leroy, C.; Dejean, A.; Corbara, B. Ants mediate the structure of phytotelm communities in an ant-garden bromeliad. Ecology 2010, 91, 1549-1556. [CrossRef] [PubMed]

58. Swofford, D.L. PAUP: Phylogenetic Analysis Using Parsimony ( ${ }^{*}$ and other Methods), Version 4.0; Sinauer Associates: Sunderland, MA, USA, 2002.

59. McNally, R.; Fleishman, E. Using indicator species to model species richness: Model development and predictions. Ecol. Appl. 2002, 12, 79-92. [CrossRef]

60. Nally, R.M.; Fleishman, E. A successful predictive model of species richness based on indicator species. Conserv. Biol. 2004, 18, 646-654. [CrossRef]

61. Geiger, W. Insekten und Naturschutz. Überlegungen aus der Schweiz. Mitt. Dtsch. Ges. Allg. Angew. Entomol. 1992, 8, 19-22.

62. Young, A.M. Population Biology of Tropical Insects; Plenum: New York, NY, USA; London, UK, 1982; pp. 1-460.

63. Jones, R.E.; Rienks, J. Reproductive seasonality in the tropical genus Eurema (Lepidoptera: Pieridae). Biotropica 1987, 19, 7-16. [CrossRef]

64. Kunte, K.J. Project life scape. Resonance 2000, 5, 86-97. [CrossRef]

65. Amala, S.; Rajkumar, M.; Anuradha, V. Species richness of Butterflies in the selected areas of Siumalai Hills. IJPAS 2011, 5, 9-15.

66. Chakravarthy, A.K.; Rajagopal, D.; Jaganmathan, R. Insects as bio-indicators of conservation in the tropics. Zoo's Print 1997, 12, 21-25.

67. Warren, A.D.; Davis, K.J.; Grishin, N.V.; Pelham, J.P.; Stangeland, E.M. Interactive Listing of American Butterflies. [30-XII-2012]. Available online: http://www.butterfliesofamerica.com/ (accessed on 27 November 2019).

68. Kalacskaa, M.; Sanchez-Azofeifaa, G.A.; Calvo-Alvaradob, J.C.; Quesadac, M.; Rivarda, B.; Janzen, D.H. Species composition, similarity and diversity in three successional stages of a seasonally dry tropical forest. For. Ecol. Manag. 2004, 200, 227-247. [CrossRef]

69. Van Halder, I.; Barbaro, L.; Jactel, H. Conserving butterflies in fragmented plantation forests: Are edge and interior habitats equally important? J. Insect Conserv. 2011, 15, 591-601. [CrossRef]

70. Machkour-M'Rabet, S.; Hénaut, Y.; Calmé, S.; Legal, L. When landscape modification is advantageous for protected species. The case of a synanthropic tarantula, Brachypelma vagans. J. Insect Conserv. 2012, 16, 479-488. [CrossRef]

71. Cavanzón-Medrano, L.; Machkour-M’Rabet, S.; Chablé-Iuit, L.; Pozo, C.; Hénaut, Y.; Legal, L. Effect of climatic conditions and land cover on genetic structure and diversity of Eunica tatila (Lepidoptera) in the Yucatan peninsula, Mexico. Diversity 2018, 10, 79. [CrossRef] 
72. Lobo, J.A.; Quesada, M.; Stoner, K.E.; Fuchs, E.J.; Herrerías-Diego, Y.; Rojas, J.; Saborío, G. Factors affecting phenological patterns of bombacaceous trees in seasonal forests in Costa Rica and Mexico. Am. J. Bot. 2003, 90, 1054-1063. [CrossRef] [PubMed]

73. Usher, M.B.; Keiller, S.W. The macrolepidoptera of farm woodlands: Determinants of diversity and community structure. Biol. Conserv. 1998, 7, 725-748. [CrossRef]

74. Holling, C.S. Resilience and stability of ecological systems. Annu. Rev. Ecol. Evol. Syst. 1973, 4, 1-23. [CrossRef]

75. Elmqvist, T.; Pyykönen, M.; Tengö, M.; Rakotondrasoa, F.; Rabakonandrianina, E.; Radimilahy, C. Patterns of Loss and Regeneration of Tropical Dry Forest in Madagascar: The Social Institutional Context. PLoS ONE 2007, 2, e402. [CrossRef] [PubMed]

76. Green, G.M.; Sussman, R.W. Deforestation history of eastern rain forests of Madagascar from satellite images. Science 1990, 248, 212-215. [CrossRef] [PubMed]

77. Sussman, R.W.; Green, G.M.; Sussman, L.K. Satellite Imagery, Human-Ecology, Anthropology, and Deforestation in Madagascar. Hum. Ecol. 1994, 22, 333-354. [CrossRef]

78. Sussman, R.W.; Green, G.M.; Porton, I.; Andrianasolondraibe, O.L.; Ratsirarson, J. A Survey of the Habitat of Lemur catta in Southwestern and Southern Madagascar. Primate Conserv. 2003, 19, 32-57.

79. Stan, K.; Sanchez-Azofeifa, A. Tropical dry forest diversity, climatic response, and resilience in a changing climate. Forests 2019, 10, 443. [CrossRef]

80. Vallauri, D.; Géraux, H. Recréer des Forêts Tropicales Sèches en Nouvelle Calédonie; WWF: France, Paris, 2004; pp. 1-28.

81. Soberón, J.; Peterson, A.T. Interpretation of models of fundamental ecological niches and species' distributional areas. Bioinformatics 2005, 2, 1-10. [CrossRef]

82. Tucker, C.M.; Munroe, D.K.; Nagendra, H.; Southworth, J. Comparative spatial analyses of forest conservation and change in Honduras and Guatemala. Conserv. Soc. 2005, 3, 174-200.

(C) 2020 by the authors. Licensee MDPI, Basel, Switzerland. This article is an open access article distributed under the terms and conditions of the Creative Commons Attribution (CC BY) license (http://creativecommons.org/licenses/by/4.0/). 